
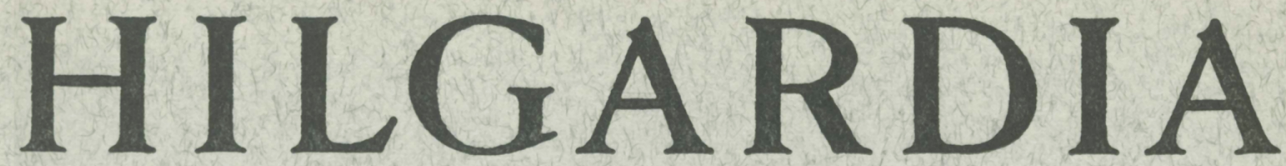

A Journal of Agricultural Science Published by the California Agricultural Experiment Station

\title{
PHYSICAL AND CHEMICAL CHANGES IN FRENCH PRUNES DURING MATURATION IN COASTAL VALLEYS
}

L. L. CLAYPOOL, W. H. DEMPSEY, PAUL ESAU and $M$. W. MILLER

THE INFLUENCE OF HARVESTING PROCEDURES AND STORAGE ON THE QUALITY OF DRIED FRENCH PRUNES FROM COASTAL REGIONS

L. L. CLAYPOOL, M. W. MILLER, W. H. DEMPSEY and PAUL ESAU

UNIVERSITY OF CALIFORNIA • BERKELEY, CALIFORNIA 


\title{
THE INFLUENCE OF HARVESTING PROCEDURES AND STORAGE ON THE QUALITY OF DRIED FRENCH PRUNES FROM COASTAL REGIONS ${ }^{1,2}$
}

\author{
L. L. CLAYPOOL, ${ }^{3}$ M. W. MILLER, ${ }^{4}$ W. H. DEMPSEY ${ }^{5}$ \\ and PAUL ESAU
}

INTRODUCTION

The PRUNE INDUSTRY of California, aware of increasing competition for the consumer food dollar, expects that any competitive gains will come primarily from improving the appearance and flavor of prunes. The quality of prunes may vary greatly under quite uniform conditions of processing and storage. Many of the factors responsible are found in the prunes themselves and are the consequence of microclimate, cultural practices, size of crop, maturity, and harvest procedure. The last two are subject to considerable control and were studied as part of a comprehensive research program during the 4-year period, 1950-1953. The four major varieties of prunes produced for drying in California were studied in their principal areas of production.

Additional studies were begun in 1956 to gain more information on coastal valley prunes. The results presented here show how multiple harvests influence the quality of the dried product.

\section{METHODS}

Prunes are harvested by being shaken from the tree, but in California's interior valley shaking is usually not selective for maturity and prunes of all maturities drop at about the same level of energy. This is because abseission layers are usually not formed. In cooler coastal climates, abscission layers do form, and shaking can be selective for maturity. Since ease of fruit removal by shaking is associated with temperature there can be considerable variation in the behavior of prunes in different orchards in any one year, or in a single orchard in different years. This is particularly true of orchards in parts of Napa and Sonoma counties, where the climate may fluctuate from year to year between coastal and interior valley conditions.

Because of lack of abscission, all prunes in interior valley orchards are removed at one harvest. In coastal valleys, two to four harvests are customary.

\section{Selection of Plots}

Several weeks before the harvest season, plots were selected in seven coastal valley orchards (see table 1) considered representative of the prune or-

\footnotetext{
${ }^{1}$ Work done under contract with the U. S. Department of Agriculture and authorized by the Research and Marketing Act of 1946. The contract was supervised by the Western Utilization Research and Development Division of the Agricultural Research Service.

${ }^{2}$ Submitted for publication January 6, 1961.

${ }^{3}$ Professor of Pomology and Pomologist in the Experiment Station, Davis.

${ }^{4}$ Assistant Professor of Food Sciences and Assistant Food Technologist in the Experiment Station, Davis.

${ }^{5}$ Associate Professor of Agriculture, Chico State College, California.

${ }^{6}$ Laboratory Technician IV in the Experiment Station, Davis.
} 
chards in that area. Three of the orchards were in the Gilroy-Morgan Hill area of Santa Clara County, two in Sonoma County, and two in Napa County. The Santa Clara orchards were quite similar in climate but were on different soils. The four orchards in Sonoma and Napa varied considerably in microclimates. Two were somewhat intermediate between coastal and interior valley, varying in tendency from year to year. The other two orchards (2 and

TABLE 1

LOCATION OF TEST PLOTS

(1956 AND 1957)

\begin{tabular}{l|l|l|l|l|l|l}
\hline \hline Orchard & \multicolumn{1}{|c|}{ Location } & Soil type & $\begin{array}{c}\text { Irri- } \\
\text { gation }\end{array}$ & $\begin{array}{c}\text { Tree } \\
\text { condi- } \\
\text { tion }\end{array}$ & \multicolumn{1}{|c|}{$\begin{array}{c}\text { Age } \\
\text { Usual } \\
\text { number } \\
\text { of } \\
\text { harvests }\end{array}$} \\
\hline $1 \ldots \ldots \ldots$ & Rutherford (Napa) & Zamora silty clay loam & Yes & Excellent & Middle & 3 \\
$2 \ldots \ldots \ldots$ & Yountville (Napa) & Bale loam & No & Poor & Old & 2 \\
$3 \ldots \ldots \ldots$ & Healdsburg (Sonoma) & Yolo fine sandy loam & Yes & Good & Middle & 4 \\
$4 \ldots \ldots \ldots$ & 10 miles NE Healdsburg (Sonoma) & Yolo loam & No & Good & Old & 2 \\
$5 \ldots \ldots \ldots$ & Gilroy (Santa Clara) & Yolo silt loam & Yes & Fair & Old & 3 \\
$6 \ldots \ldots \ldots$ & Gilroy (Santa Clara) & Yolo gravelly loam & Yes & Good & Middle & 4 \\
$7 \ldots \ldots \ldots$ & Morgan Hill (Santa Clara) & Pinole clay loam & Yes & Fair & Young & 3 \\
\hline
\end{tabular}

3 in table 1) were representative of the cooler coastal valley areas where prunes are grown.

Each orchard had three plots, respectively scheduled for harvest in 2, 3 and 4 picks. Plots consisted of three trees as nearly representative as possible of the average size of tree and crop. The same orchards were used each year, though not necessarily the same trees. 1956 was a heavy crop year, and 1957 was a light to normal crop year. Crop size for the two years varied greatly in some test orchards, and only slightly in others.

\section{Harvest Procedure}

Harvesting was begun on experimental plots when commercial harvest started in the area, and was continued until the grower or area completed harvest. An attempt was made to stagger harvests in such a way that the 4-pick plot had its initial harvest ahead of the other plots and was completed after other plots. The 3 and 2-pick plots had their harvests spaced, with the 2 pick plot being started after the 4 and 3-pick plots and completed before them. Because of problems associated with collections, it was not possible to develop as precise a pattern of collections as was desired, but the schedule used is believed to have yielded pertinent data for comparing different procedures.

Actual harvesting was accomplished by gathering all fruit dropped naturally, which were then designated "ground" fruit (G). Trees were then shaken lightly to cause riper fruits to drop. These were usually caught on a canvas and were designated "tree" fruit (T). At the time of final harvest, the relatively wide range of maturity of the remaining fruits often made it necessary to shake much more vigorously to cause all fruits to drop.

A plot sample consisted of 40 pounds of ground fruit and 40 pounds of 
tree fruit when that much was available, and was always representative of the three trees in the plot. Harvested fruit was taken to Davis, usually on the same day. Then, after thorough mixing, subsamples of each $\mathrm{T}$ and $\mathrm{G}$ lot were ready for study. Remaining fruits were dried in an experimental dehydrator.

\section{Dehydration Procedure}

At the dehydrator inedible and damaged prunes were removed from the fresh fruit samples. The selected fruit was weighed, spread on $2 \times 3$-foot stainless steel mesh trays, and thoroughly washed with a cold-water spray. About $21 / 2$ to 3 pounds of fruit were spread per square foot of tray space.

The prunes were dried under conditions simulating those found in commercial counter-current dehydration of prunes. The air temperature and humidity were automatically controlled to ensure similar drying conditions for all samples. The dry-bulb temperature started at $135^{\circ} \mathrm{F}$ and reached a maximum of $165^{\circ} \mathrm{F}$ in about 18 hours. Fruit was removed from the dehydrator when moisture content was about 18 per cent. When there was a wide range of sizes within a sample, fruit was removed from the dehydrator when the smaller ones reached about 18 per cent moisture content. Drying of larger-sized fruits was completed at atmospheric temperature. This procedure minimized heat damage.

\section{Physical and Chemical Tests of Fresh Prunes}

In 1956, physical and chemical tests of the fresh fruit included flesh firmness, color, per cent soluble solids, total solids, $\mathrm{pH}$, and acidity. The tests were the same in 1957 except for total solids. Tests were made the day after harvest, following overnight storage at $31^{\circ} \mathrm{F}$.

Flesh Firmness. Flesh firmness was determined on the pared cheeks with a Ballauf $0-10$ pound pressure tester having a $5 / 16$-inch tip. The average of at least 20 tests, usually on 20 representative prunes selected at random, was used as a lot average. The $5 / 16$-inch tip was used in preference to the $7 / 16^{-i n c h}$ tip because prunes are relatively small and the larger tip would have required a deeper paring to remove the skin and give a flat surface.

Flesh Color. From the sample taken for physical and chemical tests a subsample of 10 prunes was taken for subjective flesh color determinations, excluding moldy or damaged fruit. After removal of a thin slice of skin and outer flesh, a slice about 1/8-inch thick was cut parallel to the suture. Sharp, thin-bladed stainless-steel knives were used. The slice was then trimmed to a rectangle approximating that of a color chip in the Maerz and Paul "Dictionary of Color" (1930) and the colors matched. All color comparisons were made under artificial light only, obtained by pairing KenRad 40W White and Daylight tubes. The data collected were converted to the Munsell system of notation, which in turn was converted into the CIE system (Esau, 1958).

Flesh color was also measured objectively, with a Colormaster Differential Colorimeter. At least 33 prunes were peeled, pitted, and immediately dropped into a solution of $\mathrm{NaCl}$ and ascorbic acid to inhibit browning. The

${ }^{7}$ See "Literature Cited" for citations, referred to in text by author and date. 
$200 \mathrm{ml}$ of solution used for each sample contained 100 grams $\mathrm{NaCl}$ and 3.0 grams ascorbic acid per liter. When all prunes were submerged the contents were emptied at once onto a stainless-steel screen, drained 3 to 5 minutes, and then homogenized for 1 minute in a blender. Two hundred and fifty milliliters of the homogenate was centrifuged for 8 to 9 minutes at $2000 \mathrm{rpm}$ (International centrifuge, model $\mathrm{V}$, size 2 ). The upper portion containing air bubbles was decanted and the remainder was placed in the colorimeter sample holder so that no air was entrapped and was covered with a black cover-plate. Readings of the sample were made in two positions of the colorimeter, and the averages were converted to CIE color values.

Per Cent Soluble Solids. The fruits tested for flesh firmness were usually used for chemical determinations. After removal of the pits the flesh was macerated in a blender. Soluble solids in a slurry sample were read with either a Zeiss hand refractometer or a Zeiss-Abbe refractometer.

Per Cent Total Solids. Total solids were determined by drying an approximately 10-gram portion of the slurry according to the AOAC vacuum oven method (Association of Official Agricultural Chemists, 1945).

$\mathrm{pH}$ and Acidity. The $\mathrm{pH}$ of the slurry was determined with a Beckman $\mathrm{pH}$ meter. Acidity was determined by titrating to $\mathrm{pH} 7 \mathrm{a} 10 \mathrm{ml}$ sample of slurry, diluted with $50 \mathrm{ml}$ of distilled water, using the Beckman $\mathrm{pH}$ meter. Acidity is expressed as $\mathrm{ml} 0.1 \mathrm{~N}$ alkali to titrate $10 \mathrm{ml}$ of slurry to $\mathrm{pH} 7$.

\section{Physical and Chemical Tests of Dried Prunes}

In 1956 and 1957 dehydrated prunes were tested for moisture content and flesh color. They were also inspected and graded for commercial acceptability, rate of rehydration, and evaluated organoleptically.

Moisture Content. The percentage of moisture remaining in the dried prunes after dehydration was determined by the $\mathrm{AOAC}$ vacuum oven method or by the elcetrical conductivity method, using a Dried Fruit Association of California electrical moisture tester. All dried fruit data were calculated to reflect an equal moisture content of 18 per cent.

Flesh Color. The flesh color of the dried fruit was determined objectively with a Colormaster Differential Colorimeter. The procedure was similar to that used for the objective color evaluation of the fresh fruit flesh except that, prior to peeling and pitting, the dried prunes were rehydrated in boiling water for 10 minutes to permit removal of the skin.

Inspection and Grading. All samples were graded for commercial acceptability on the basis of external skin color and appearance, and upon flesh color and condition by industry inspectors and university personnel familiar with the concepts of prune quality. The number and size of gas pockets were ascertained when the dried fruits were cut for the judging of flesh color and condition.

Organoleptic Evaluation. Sensory testing of acceptability was done by a panel of seven judges selected from an initial group of fifteen for consistent discrimination among prunes of varying quality in a preliminary training program.

The paired comparison design was used for determining the sample in each 
pair that had more natural prune flavor and a more tender texture. One to two pairs were evaluated per panel session.

Preparation of the dried fruit for serving included an initial washing and draining, and soaking of prunes for 15 hours in tap water in the proportions of 1 part prunes to 3 parts water. After the soaking period the prunes were brought to a boil, simmered for 40 minutes, and cooled slowly at room temperature. One hour before being served, the prunes were drained and cut into halves. The prunes, 5 to 6 halves per serving, were served in white sauce dishes coded with random two-digit numbers. Serving order was random.

The evaluation was done in individual tasting booths under low red illumination to mask color differences.

Rate of Rehydration. The rate of water uptake by dried prunes was measured by the gain in weight of 1-pound samples. The samples were immersed in boiling water for 2 minutes, drained for 2 minutes, weighed, and immersed again for similar periods. Total immersion time was 8 to 10 minutes. The rate was determined by the slope of plotting weight gain against time of immersion.

\section{RESULTS}

The 1956 and 1957 seasons were quite different climatically and in crop size. Although the amount of crop as measured by number of fruits is not related to the climate during the season of fruit growth and maturation, both climate and crop size are variables that influence the size, composition and resultant quality of prunes. The crop was very heavy in 1956 in most coastal valley orchards, though some orchards were much heavier laden than others, as indicated by the number of prunes per 3 -tree plot (table 2 ). The next year was more normal (table 3 ), though the crop in some orchards was quite light, perhaps partly because of the heavy crop in the preceding year. Temperatures were relatively normal in 1956, and hot from mid-June until midAugust of the summer of 1957. The extremes were somewhat less in the coastal than in the interior valleys, but average maximum temperatures in the coastal valleys were perceptibly higher in 1957 (table 4).

\section{Size of Fruit}

In 1956, prune sizes averaged small. Variation in size ranged (in individual plots) from 59 to 186 dried prunes per pound. In 1957, prune size were large in most plots, ranging from 33 to 74 dried prunes per pound. A study of tables 2 and 3 shows, for any one orchard, a close correlation between number of prunes per tree and prune size; again, some variation existed between the size of trees and between the number of fruits in relation to tree size. These uncontrolled variables account for much of the fruit count and size variation between plots in a single orchard in any one year.

The same trees were not necessarily used in 1956 and 1957, as an effort was made each year to select plots from a block of trees of somewhat comparable size and crop. Therefore, a comparison of variations in the number of fruits by individual plots is not valid, though a comparison of the size of crop in different orchards in the two years is valid. Differences in tree size, age, and 
TABLE 2

NUMBER AND WEIGHT OF PRUNES HARVESTED FROM PLOTS OF THREE TREES EACH IN 1956

\begin{tabular}{|c|c|c|c|c|c|c|c|c|c|}
\hline \multirow{3}{*}{ Orchard and district } & \multicolumn{9}{|c|}{ Source and quantity of fruit } \\
\hline & \multicolumn{3}{|c|}{4 pick } & \multicolumn{3}{|c|}{3 pick } & \multicolumn{3}{|c|}{2 pick } \\
\hline & Tree & Ground & Total & Tree & Ground & Total & Tree & Ground & Total \\
\hline \multicolumn{10}{|l|}{ 1-NAPA } \\
\hline Number of fruit & $\ldots$ & $\ldots$ & $\ldots$ & 12,152 & 6,964 & 19,116 & 14,392 & 2,974 & 17,366 \\
\hline Fresh weight, pounds... & $\ldots$ & $\ldots$ & $\ldots$ & 384 & 159 & 543 & 560 & 103 & 663 \\
\hline Dried weight, $\mathrm{r}$ & $\ldots$ & $\ldots$ & $\ldots$ & 139 & 71 & 210 & 177 & 42 & 219 \\
\hline Count per pound, dried. & $\ldots$ & ... & $\ldots$ & 88 & 98 & 91 (av.) & 81 & 71 & 79 (av.) \\
\hline \multicolumn{10}{|l|}{$2-\mathrm{NAPA}$} \\
\hline Number of fruits.. & 34,115 & 16,991 & $\mathbf{5 1 , 1 0 6}$ & 53,715 & 19,420 & 73,135 & 40,280 & 25,421 & 65,701 \\
\hline Fresh weight, pounds.. & 800 & 320 & 1,120 & 1,015 & 298 & 1,313 & 755 & 407 & 1,162 \\
\hline Dried weight, pounds.. & 291 & 126 & 417 & 291 & 103 & 394 & 218 & 138 & 357 \\
\hline Count per pound, dried. & 117 & 135 & 123 (av.) & 185 & 189 & 186(av.) & 185 & 183 & 184 (av.) \\
\hline \multicolumn{10}{|l|}{ 3-SONOMA } \\
\hline Number of fruits & 19,992 & 10,966 & 30,958 & 13,163 & 4,646 & 17,809 & 14,657 & 9,818 & 23,575 \\
\hline Fresh weight, pounds. & 702 & 342 & 1,044 & 563 & 157 & 720 & 533 & 281 & 814 \\
\hline Dried weight, pounds.. & 245 & 134 & 379 & 195 & 58 & 253 & 185 & 110 & 295 \\
\hline Count per pound, dried. & 82 & 82 & 82 (av.) & 68 & 80 & 70 (av.) & 79 & 81 & 80 (av.) \\
\hline \multicolumn{10}{|l|}{ 4-SONOMA } \\
\hline Number of frui & 23,341 & 7,804 & 31,645 & 15,277 & 7,574 & 22,851 & 20,168 & 7,563 & 27,731 \\
\hline Fresh weight, & 1,061 & 271 & 1,332 & 606 & 238 & 844 & 876 & 235 & 1,114 \\
\hline Dried weigh & 426 & 113 & 539 & 256 & 116 & 372 & 343 & 97 & 440 \\
\hline Count per pound, dried... & 56 & 69 & 59 (av.) & 60 & 65 & 61 (av.) & 59 & 78 & 64 (av.) \\
\hline \multicolumn{10}{|l|}{ 5-SANTA CLARA } \\
\hline Number of fruits.. & 36,605 & 12,238 & 48,843 & 24,905 & 5,972 & 30,877 & 29,980 & 9,346 & 39,326 \\
\hline Fresh weight, pounds.. & 1,167 & 300 & 1,467 & 830 & 155 & 985 & 905 & 218 & 1,123 \\
\hline Dried weight, pounds... & 381 & 112 & 493 & 234 & 45 & 279 & 271 & 84 & 355 \\
\hline Count per pound, dried. . & 96 & 109 & 99 (av.) & 107 & 132 & 110(av.) & 111 & 111 & 111 (av.) \\
\hline \multicolumn{10}{|l|}{ 6-SANTA CLARA } \\
\hline Number of fruits.. & 18,770 & 7,792 & 26,562 & 14,067 & 3,938 & 18,005 & 13,965 & 10,110 & 24,075 \\
\hline Fresh weight, pounds.. & 605 & 238 & 843 & 482 & 113 & 595 & 465 & 276 & 741 \\
\hline Dried weight, pounds... & 199 & 79 & 278 & 149 & 38 & 187 & 146 & 100 & 246 \\
\hline Count per pound, dried... & 94 & 99 & 96 (av.) & 94 & 103 & 96 (av.) & 96 & 101 & 98 (av.) \\
\hline \multicolumn{10}{|l|}{ 7-SANTA CLARA } \\
\hline Number of fruits.. & 20,027 & 4,868 & 24,895 & 20,721 & 8,568 & 29,289 & 18,581 & 7,378 & 25,959 \\
\hline Fresh weight, pounds.. & 726 & 163 & 889 & 654 & 240 & 894 & 629 & 217 & 845 \\
\hline Dried weight, & 251 & 58 & 309 & 219 & 85 & 304 & 224 & 82 & 306 \\
\hline Count per pound, dried........ & 80 & 84 & 81 (av.) & 94 & 101 & 96 (av.) & 83 & 90 & 85 (av.) \\
\hline
\end{tabular}


TABLE 3

NUMBER AND WEIGHT OF PRUNES HARVESTED FROM PLOTS OF THREE TREES EACH IN 1957

\begin{tabular}{|c|c|c|c|c|c|c|c|c|c|}
\hline \multirow{3}{*}{ Orchard and district } & \multicolumn{9}{|c|}{ Source and quantity of fruit } \\
\hline & \multicolumn{3}{|c|}{4 pick } & \multicolumn{3}{|c|}{3 pick } & \multicolumn{3}{|c|}{2 pick } \\
\hline & Tree & Ground & Total & Tree & Ground & Total & Tree & Ground & Total \\
\hline \multicolumn{10}{|l|}{ 1-NAPA } \\
\hline Number of fruits. . & 29,886 & 4,030 & 33,916 & 24,189 & 3,288 & 27,477 & 19,224 & 6,649 & 25,873 \\
\hline Fresh weight, pounds. . & 966 & 113 & 1,079 & 842 & 106 & 948 & 700 & 223 & 923 \\
\hline Dried weight, pounds... & 551 & 53 & 604 & 576 & 67 & 643 & 420 & 127 & 547 \\
\hline Count per pound, dried.. & 54 & 76 & 56 (av.) & 42 & 49 & 43 (av.) & 46 & 52 & 47 (av.) \\
\hline \multicolumn{10}{|l|}{ 2-NAPA } \\
\hline Number of fruits. & 18,319 & 1,499 & 19,818 & 11,808 & 1,159 & 12,967 & 12,603 & 722 & 13,325 \\
\hline Fresh weight, pounds. & 721 & 53 & 774 & 509 & 39 & 548 & 459 & 26 & 485 \\
\hline Dried weight, pounds. & 399 & 30 & 429 & 205 & 19 & 224 & 276 & 14 & 290 \\
\hline Count per pound, dried. & 46 & 50 & 46 (av.) & 57 & 61 & 58 (av.) & 46 & 52 & 46 (av.) \\
\hline \multicolumn{10}{|l|}{ 3-SONOMA } \\
\hline Number of fruits & 21,422 & 8,386 & 29,808 & 15,296 & 12,052 & 27,348 & 14,920 & 4,007 & 18,927 \\
\hline Fresh weight, pounds. & 795 & 313 & 1,108 & 543 & 440 & 983 & 539 & 137 & 676 \\
\hline Dried weight, $\mathrm{l}$ & 301 & 126 & 427 & 205 & 167 & 372 & 205 & 53 & 258 \\
\hline Count per pound, dried ........ & 71 & 67 & 70 (av.) & 75 & 72 & 74 (av.) & 73 & 76 & 73 (av.) \\
\hline \multicolumn{10}{|l|}{ 4-SONOMA } \\
\hline Number of frui & 14,483 & 3,765 & 18,248 & 11,195 & 3,390 & 14,585 & 17,642 & 1,499 & 19,141 \\
\hline Fresh weight, $p$ & 725 & 153 & 878 & 461 & 142 & 603 & 754 & 53 & 807 \\
\hline Dried weight, pounds... & 355 & 87 & 442 & 296 & 78 & 374 & 414 & 29 & 443 \\
\hline Count per pound, dried... & 41 & 43 & 41 (av.) & 38 & 44 & 39 (av.) & 42 & 52 & 43 (av.) \\
\hline \multicolumn{10}{|l|}{ 5-SANTA CLARA } \\
\hline Number of fruits. & 17,690 & 2,155 & 19,845 & 19,608 & 2,196 & 21,804 & 13,176 & 1,588 & 14,764 \\
\hline Fresh weight, pounds. & 703 & 75 & 778 & 790 & 70 & 860 & 488 & 52 & 540 \\
\hline Dried weight, pounds. . & 374 & 37 & 411 & 407 & 47 & 454 & 254 & 31 & 285 \\
\hline Count per pound, dried. & 47 & 58 & 48 (av.) & 48 & 47 & 48 (av.) & 52 & 51 & 52 (av.) \\
\hline \multicolumn{10}{|l|}{ 6-SANTA CLARA } \\
\hline Number of fruits.. & 6,261 & 2,026 & 8,287 & 6,516 & 1,625 & 8,141 & 7,940 & 2,155 & 10,095 \\
\hline Fresh weight, pounds. . & 286 & 94 & 380 & 308 & 65 & 373 & 349 & 92 & 441 \\
\hline Dried weight, pounds. . & 201 & 48 & 249 & 183 & 44 & 227 & 188 & 44 & 232 \\
\hline Count per pound, dried.. & 31 & 42 & 33 (av.) & 36 & 37 & 36 (av.) & 42 & 49 & 44 (av.) \\
\hline \multicolumn{10}{|l|}{ 7-SANTA CLARA } \\
\hline Number of fruits.. & 8,957 & 878 & 9,835 & 13,702 & 1,792 & 15,494 & 16,475 & 3,837 & 20,312 \\
\hline Fresh weight, pounds. . & 347 & 29 & 376 & 426 & 52 & 478 & 524 & 94 & 618 \\
\hline Dried weight, pounds.... & 156 & 12 & 168 & 188 & 20 & 208 & 301 & 45 & 346 \\
\hline Count per pound, dried......... & 57 & 73 & 59 (av.) & 73 & 90 & 75 (av.) & 55 & 85 & 59 (av.) \\
\hline
\end{tabular}


cultural factors make comparisons difficult between orchards in number and size of fruits.

The most striking example of variations between crop and fruit size is in orchard 2. In 1956, the 9 test trees produced 192,000 prunes having a total dried weight of 1,168 pounds and a count per pound of 164 . In 1957, the 9 test trees produced only 46,000 prunes, or 24 per cent of the 1956 crop. However, because of the much larger fruit size (49 per pound) the total dried

TABLE 4

TEMPERATURE DATA FOR VARIOUS DISTRICTS

\begin{tabular}{|c|c|c|c|c|c|}
\hline \multirow{2}{*}{ District } & \multicolumn{5}{|c|}{ Average daily maximums } \\
\hline & Year & June & July & August & September \\
\hline & & ${ }^{\circ} \mathrm{F}$ & ${ }^{\circ} \mathrm{F}$ & ${ }^{\circ} \mathrm{F}$ & ${ }^{\circ} \mathrm{F}$ \\
\hline \multirow[t]{2}{*}{ San Jose* } & 1956 & 80.2 & 81.1 & 81.3 & 82.4 \\
\hline & 1957 & 84.8 & 84.8 & 83.0 & 83.0 \\
\hline \multirow[t]{2}{*}{ Napat. } & 1956 & 83.2 & 79.1 & 80.8 & 83.8 \\
\hline & 1957 & 84.7 & 84.4 & 80.2 & \\
\hline \multirow[t]{2}{*}{ Sonomał. } & 1956 & 86.5 & 83.7 & 85.0 & 84.7 \\
\hline & 1957 & 88.6 & 87.8 & 87.6 & 83.5 \\
\hline
\end{tabular}

* University of California, Deciduous Fruit Field Station, San Jose, California.

$\dagger$ U. S. Weather Bureau data from Napa State Hospital, Napa, California.

$\ddagger$ U. S. Weather Bureau data, Healdsburg, California.

fruit weight (943 pounds) was 80 per cent of that of the 1956 crop. On the other hand, orchard 3 was quite uniform in both years, producing 72,000 fruits averaging 78 per pound from 9 trees in 1956 and 76,000 prunes averaging 72 per pound in 1957. These comparisons indicate that the size differences in prunes between the two years in any orchard are due primarily to differences in number of prunes per tree.

Size differences in dried prunes between the 1956 and 1957 erop years are also reflected in the drying ratios obtained (the pounds of fresh fruit required to produce 1 pound of dried fruit). A general correlation is found between the size (count per pound) and the drying ratio. The larger sizes of dried fruit are correlated with the smaller drying ratios. The soluble solids content influences the drying ratio, but this can be misleading unless there is information about the amount of dehydration actually occurring to the fruit while still on the tree. This factor varies in importance, depending on the year, size of crop and climatic conditions in the area of production.

Because fruits are harvested at uniform maturity in the coastal valleys, and because fully mature fruits may drop to the ground, the degree of dehydration is approximately the same for all the tree-harvested fruits. Under these conditions the smaller drying ratios correlate with the larger fruits because of the latter's higher soluble solids content. Since the rate of dehydration on the tree (climate conditions being the same) is partially determined by the surface-to-volume ratio of the individual fruits, smaller fruits would be influenced to a greater extent than larger fruits. 


\section{Flesh Firmness}

Flesh firmness is probably a truer measure of prune maturity than any other single index, with the possible exception of flesh color. Studies in 1951 and 1952 (Claypool and Kilbuck, 1956) showed that harvest could be started when the flesh firmness of prunes on the tree averaged about 4 pounds in both interior areas and coastal valleys. Studies of tagged fruit lots in

TABLE 5

AVERAGE FIRMNESS OF TREE-HARVESTED FRESH PRUNES FROM PLOTS IN 1956 AND 1957

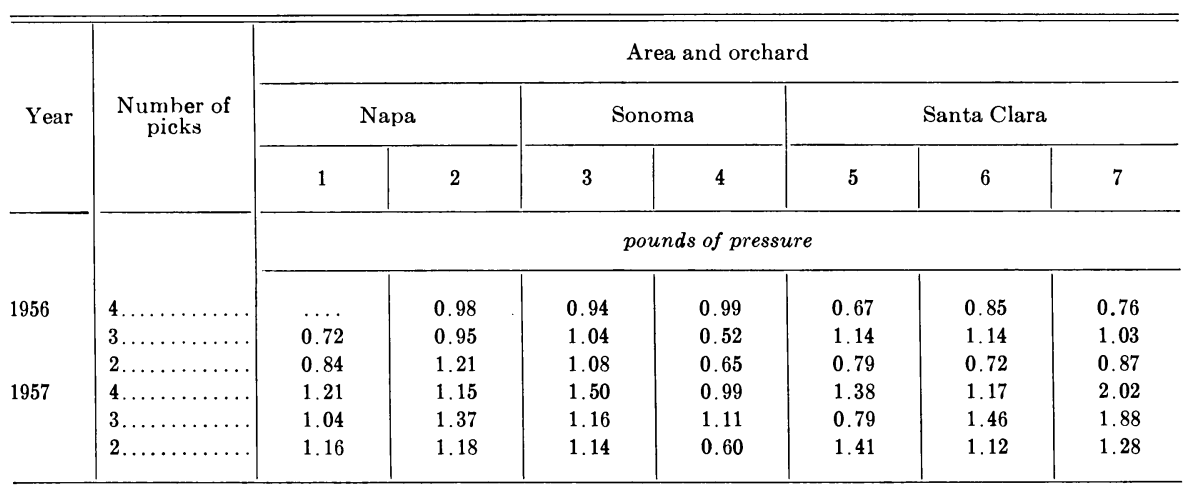

* On Ballauf 0-10 pound pressure tester having 5/16" tip.

coastal areas in 1956 and 1957 (Claypool, Dempsey, Esau, and Miller, 1962) showed that average firmness at the beginning of harvest was between 3.0 and 3.5 pounds in 1956, and 4.0 to 4.5 pounds in 1957. In 1956, growers were anxious to raise soluble solids content as much as possible because of the heavy crop and small fruit size, and therefore they delayed harvest. In 1957, with a smaller crop, solids content was higher and harvest was begun at a somewhat higher average flesh firmness.

Table 5 shows the average firmness of fresh prunes from the various plots in both 1956 and 1957. In most lots in 1956 firmness at harvest averaged 0.9 pounds; in 1957 the average of all lots exceeded 1.2 pounds. In 1956 prunes shaken at the first harvest averaged about 0.8 pounds firmness, compared to an on-the-tree average from tagged fruit studies (Claypool, Dempsey, Esau, and Miller, 1962) of between 3.0 and 3.5 pounds. Comparable figures for 1957 are 1.5 pounds firmness for first-harvest fruit and about 4.5 pounds tree average from tagged fruit studies.

These data also show the high degree of selectivity for maturity that may exist under coastal conditions when the trees are given a light-to-moderate shake.

\section{Soluble Solids}

The excessive crop in most orchards in 1956 resulted in relatively low soluble solids, and the harvest in relation to maturity (as measured by flesh firmness) was delayed in the hope of increasing the solids content. In 1957, matu- 
rity was delayed by climatic conditions but soluble solids were relatively high and harvest was begun while the fruit was still firm to the touch. Table 6 gives a summary of soluble solids by orchards for these two years.

In 1956, differences in soluble solids content of fruits between orchards were great. These differences were very closely associated with size of crop (table 2); in 1957, the differences were less marked because of the smaller crop (table 3). Orchard 6 had high solids and a light crop. Orchard 3 had

TABLE 6

WEIGHTED AVERAGE PER CENT OF SOLUBLE SOLIDS

IN FRESH PRUNES HARVESTED FROM PLOTS, 1956 AND 1957

\begin{tabular}{|c|c|c|c|c|c|c|c|c|c|c|}
\hline \multirow{3}{*}{ Year } & \multirow{3}{*}{$\begin{array}{l}\text { Number } \\
\text { of picks }\end{array}$} & \multirow{3}{*}{ Source } & \multicolumn{7}{|c|}{ Area and orchard } & \multirow{3}{*}{$\begin{array}{l}\text { Aver- } \\
\text { ages }\end{array}$} \\
\hline & & & \multicolumn{2}{|c|}{ Napa } & \multicolumn{2}{|c|}{ Sonoma } & \multicolumn{3}{|c|}{ Santa Clara } & \\
\hline & & & 1 & 2 & 3 & 4 & 5 & 6 & 7 & \\
\hline \multirow{10}{*}{1956} & \multirow{3}{*}{4} & \multirow{3}{*}{$\begin{array}{l}\text { Tree } \ldots \ldots \ldots \ldots \ldots \ldots \\
\text { Ground } \ldots \ldots \ldots \ldots \ldots\end{array}$} & \multicolumn{7}{|c|}{ per cent } & \multirow{3}{*}{26.0} \\
\hline & & & $\ldots$ & 24.1 & 27.2 & 28.6 & 22.3 & 25.5 & 28.2 & \\
\hline & & & $\ldots$ & 24.3 & 29.1 & 29.9 & 21.3 & 21.7 & 27.3 & \\
\hline & \multirow[t]{2}{*}{3} & Tree.... & 27.8 & 23.2 & 27.8 & 31.2 & 22.3 & 22.7 & 23.8 & \multirow[t]{2}{*}{25.5} \\
\hline & & Ground. & 29.0 & 22.4 & 26.8 & 28.9 & 20.2 & 21.8 & 22.7 & \\
\hline & \multirow[t]{2}{*}{2} & Tree.... & 24.8 & 22.9 & 27.6 & 28.8 & 24.1 & 24.7 & 24.7 & \multirow[t]{3}{*}{25.4} \\
\hline & & Ground.. & $\ldots$ & 23.2 & 27.1 & 28.9 & 24.1 & 24.0 & 22.9 & \\
\hline & \multirow[t]{3}{*}{ Average } & $T$ & 00 & & & & & & & \\
\hline & & Tree....... & 26.3 & 23.4 & 27.5 & 29.3 & 22.9 & 24.4 & 25.6 & \multirow[t]{2}{*}{25.6} \\
\hline & & Ground.. & $\cdots$ & 23.2 & 27.9 & 29.3 & 22.0 & 22.7 & 24.0 & \\
\hline \multirow[t]{8}{*}{1957} & \multirow[t]{2}{*}{4} & Tree........ & 26.6 & 26.8 & $\ldots$ & 29.1 & 29.2 & 31.5 & 27.7 & \multirow[t]{2}{*}{28.5} \\
\hline & & Ground.. & 28.2 & 28.0 & 28.8 & 28.7 & 28.3 & 30.1 & 26.1 & \\
\hline & \multirow[t]{2}{*}{3} & Tree.......... & 29.8 & 26.9 & 29.4 & 29.3 & 29.4 & 31.7 & 28.3 & \multirow[t]{2}{*}{29.3} \\
\hline & & Ground............. & 27.3 & 26.1 & 27.5 & 30.9 & 28.8 & 33.9 & 26.7 & \\
\hline & \multirow[t]{2}{*}{2} & Tree................ & 28.1 & 29.2 & 28.0 & 29.0 & 27.9 & 31.2 & 29.3 & \multirow[t]{2}{*}{29.0} \\
\hline & & Ground $\ldots \ldots \ldots \ldots$ & 29.3 & 26.6 & 30.0 & 32.3 & 28.2 & 32.3 & 30.0 & \\
\hline & \multirow{2}{*}{ Average } & Tree... & 28.2 & 27.6 & 28.7 & 29.1 & 28.8 & 31.5 & 28.4 & \multirow[t]{2}{*}{28.9} \\
\hline & & Ground............. & 28.5 & 27.1 & 28.4 & 30.2 & 28.4 & 31.9 & 28.4 & \\
\hline
\end{tabular}

a moderate crop each year, and only about 1 per cent difference in soluble solids for comparable harvest lots. The size of crop in orchard 4 varied somewhat between years, but the crop was not excessively large in 1956, as indicated by dried fruit size. The soluble solids content in this orchard was good in both years.

Average soluble solids content of fruits harvested in 4, 3, and 2 picks showed no consistent or significant differences associated with number of harvests. This would indicate that the grower will harvest about the same tonnage in all of these procedures, assuming that he does not shake hard enough to remove immature fruit before the clean-up harvest. Dried fruit quality will not necessarily be the same where harvest procedure varies, and will be influenced by climatic factors.

Table 7 shows a calculation of the soluble solids content of tree-harvested fruit at each harvest. With one exception, soluble solids were lower in the 
first harvest than in any other. Thus the first harvest seems to have sacrificed sugar content. As prunes may lose 10 to 12 per cent of their weight during the harvest period, loss of moisture and consequent concentration of solids could account in part for the higher content in later harvests. This does not mean that movement of solids into the fruit ceases after size starts to decrease-tagged fruits have shown some dry weight increase after all fruits are diminishing in size while attached to the tree. Unlike the interior

TABLE 7

AVERAGE PER CENT SOLUBLE SOLIDS OF PRUNES

IN RELATION TO NUMBER OF PICKS AND HARVEST SEQUENCE

\begin{tabular}{|c|c|c|c|}
\hline \multirow{2}{*}{$\begin{array}{c}\text { Number of } \\
\text { picks }\end{array}$} & \multirow{2}{*}{ Harvest } & \multicolumn{2}{|c|}{ Soluble solids } \\
\hline & & 1956 & 1957 \\
\hline & & per cent & per cent \\
\hline \multirow[t]{4}{*}{4} & 1. & 22.8 & 26.6 \\
\hline & 2. & 24.7 & 28.1 \\
\hline & $3 \ldots$ & 26.5 & 28.3 \\
\hline & $4 \ldots \ldots \ldots \ldots \ldots$ & 28.4 & 28.0 \\
\hline \multirow[t]{3}{*}{3} & $1 \ldots \ldots \ldots$ & 24.5 & 29.1 \\
\hline & 2 & 25.2 & 29.5 \\
\hline & 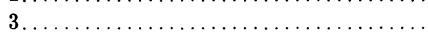 & 27.7 & 28.8 \\
\hline \multirow[t]{2}{*}{2} & $1 \ldots \ldots \ldots \ldots \ldots$ & 23.9 & 28.2 \\
\hline & $2 \ldots \ldots \ldots \ldots \ldots \ldots$ & 25.5 & 29.1 \\
\hline
\end{tabular}

valley harvest, which removes fruits of all maturities at one time, the coastal valley harvest is quite selective if shaking is light to moderate. Therefore, only fruits most advanced in maturity are likely to be removed at any except the final harvest, so that little if any sacrifice in dried fruit tonnage results.

\section{Total Solids}

Total solids determinations (made in 1956 only) are much less consistent than soluble solids determinations, and range from 6.8 per cent higher to 5.9 per cent lower than soluble solids measured by a refractometer. On the average total solids readings are about 0.8 per cent lower than soluble solids readings of similar lots of tree-harvested fruits. It is believed that much of the variability is associated with the method of determining total solids.

\section{Flesh Color}

Prune color in relation to maturity is discussed here only as it applies to this study. Claypool and Kilbuck (1956) state that the disappearance of chlorophyll from the skin and flesh of the prune is perhaps the best single index to maturity. Where there is only one pick, however, they suggest delaying harvest for about 1 week after chlorophyll disappearance so as to permit a further build-up of soluble solids in the fruit and less sacrifice in vield. Under coastal conditions there may be some variation from this be- 


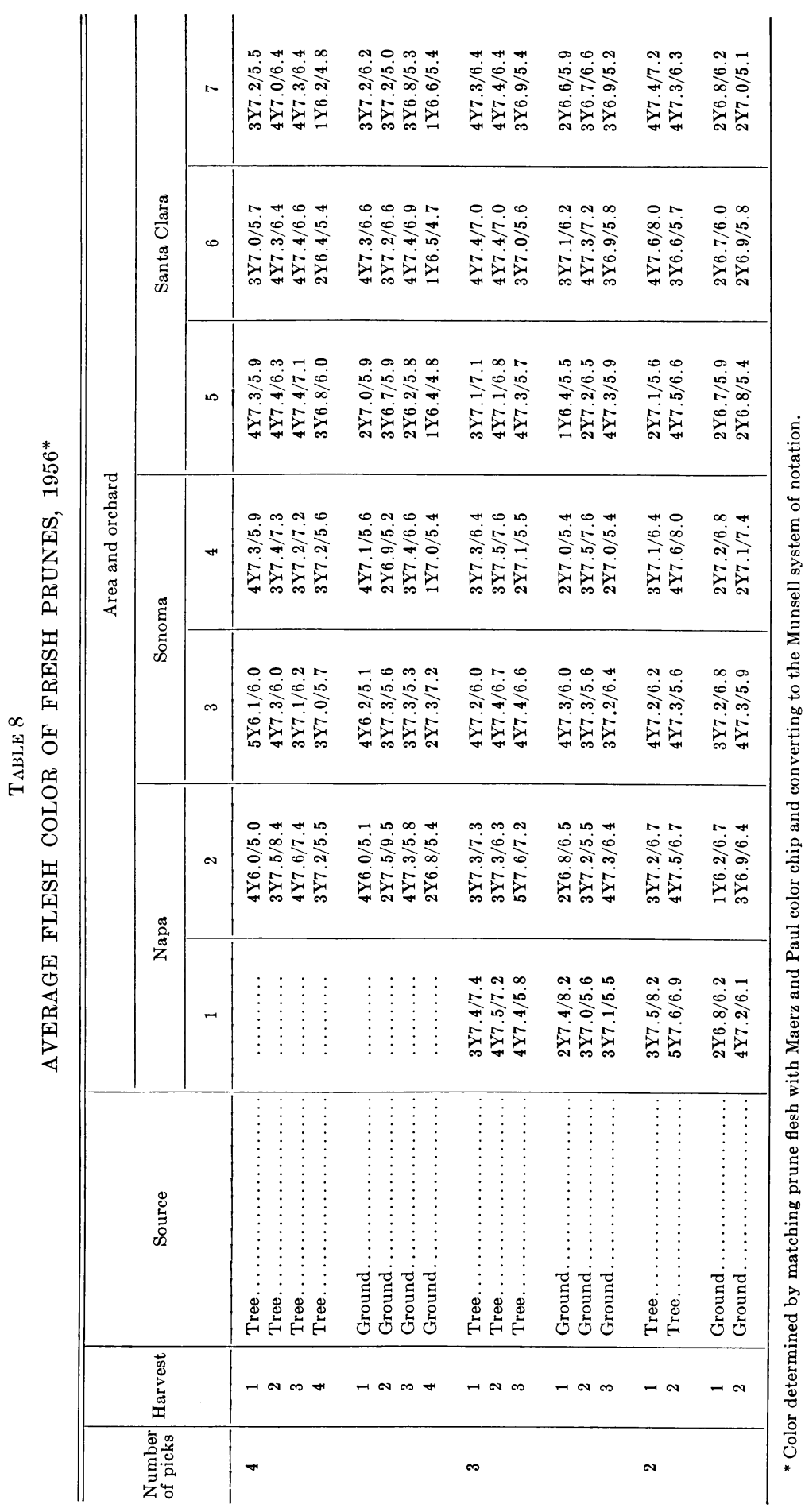




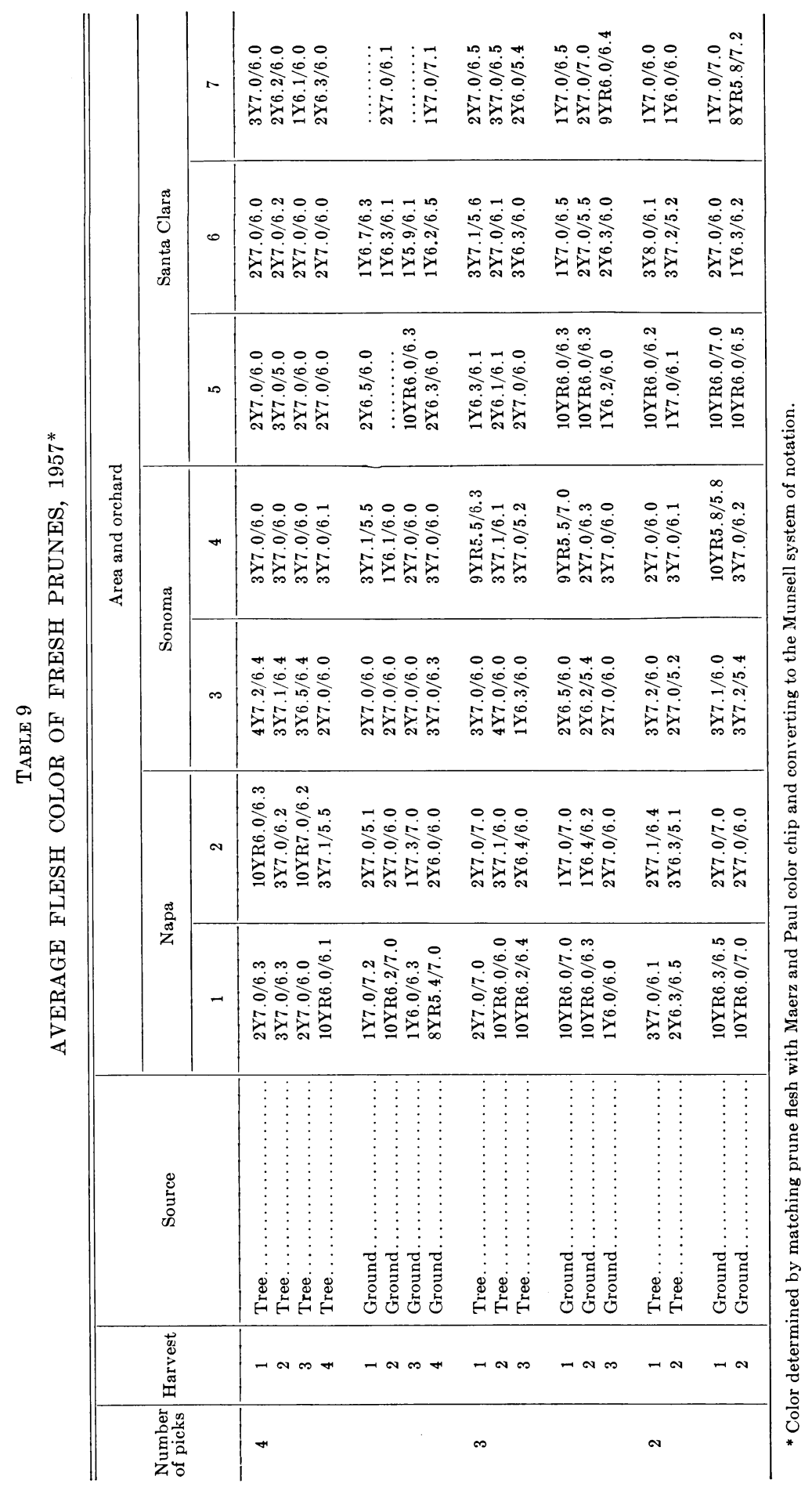


cause of multiple selective harvests. Presumably, since riper fruits from which chlorophyll had disappeared would fall most easily, it would not be necessary for all fruits to have lost green color before the beginning of harvest.

The principal change in prune color during maturation on the tree is in hue, though there may be marked differences in reflectance (amount of

TABLE 10

REFLECTANCE AND CHROMATICITY OF FRESH AND DEHYDRATED PRUNE FLESH (1956, TREE FRUIT)

\begin{tabular}{|c|c|c|c|c|c|c|c|}
\hline \multirow{3}{*}{ Orchard } & \multirow{3}{*}{ Harvest } & \multicolumn{3}{|c|}{ Fresh fruit flesh } & \multicolumn{3}{|c|}{ Dried fruit flesh } \\
\hline & & \multirow{2}{*}{$\underset{\mathrm{Y}}{\text { Reflectance }}$} & \multicolumn{2}{|c|}{ Chromaticity } & \multirow{2}{*}{$\underset{\mathrm{Y}}{\text { Reflectance }}$} & \multicolumn{2}{|c|}{ Chromaticity } \\
\hline & & & $\mathrm{x}$ & $\mathrm{y}$ & & $\mathrm{x}$ & $\mathrm{y}$ \\
\hline \multirow{5}{*}{$\begin{array}{r}\text { Santa Clara } \\
\text { Orchard } 6\end{array}$} & & per cent & & & per cent & & \\
\hline & $1 .$. & & & & 7.36 & 0.467 & 0.420 \\
\hline & & 24.47 & 0.445 & 0.450 & 8.13 & 0.474 & 0.430 \\
\hline & & 24.96 & 0.446 & 0.454 & 8.15 & 0.470 & 0.433 \\
\hline & & 19.27 & 0.456 & 0.453 & 5.92 & 0.483 & 0.430 \\
\hline \multirow{4}{*}{$\begin{array}{l}\text { Sonoma } \\
\text { Orchard } 4\end{array}$} & $1 .$. & 25.64 & 0.441 & 0.450 & 8.97 & 0.467 & 0.421 \\
\hline & $2 \ldots$ & 22.74 & 0.448 & 0.451 & 10.04 & 0.469 & 0.427 \\
\hline & & 23.06 & 0.449 & 0.453 & 9.13 & 0.485 & 0.439 \\
\hline & 4. & 19.54 & 0.450 & 0.445 & 9.32 & 0.486 & 0.440 \\
\hline \multirow{3}{*}{$\begin{array}{l}\text { Napa } \\
\text { Orchard } 1\end{array}$} & & 27.13 & 0.434 & 0.453 & 8.02 & 0.472 & 0.422 \\
\hline & & 25.70 & 0.441 & 0.451 & 9.21 & 0.476 & 0.429 \\
\hline & & 21.26 & 0.450 & 0.451 & 9.69 & 0.477 & 0.436 \\
\hline $\begin{array}{l}\text { Average for } \\
\text { all seven } \\
\text { orchards }\end{array}$ & & 23.2 & $\ldots \ldots$ & $\ldots \ldots$ & 8.72 & $\ldots \ldots$ & $\ldots \ldots$ \\
\hline
\end{tabular}

black in color) and chroma in different seasons and climatic areas. Data on tagged fruit from interior and coastal valleys showed that reflectance in interior valley prunes was perceptibly higher in 1952 than in 1951, and that in coastal valley prunes it was higher in 1956 than in 1957, though the differences were less marked. The change from yellow to yellow-red was more marked in the years when fruit was of lower reflectance. Differences in chroma did not seem to follow any pattern.

Tables 8 and 9 summarize the average flesh color of prunes harvested in coastal valleys in 1956 and 1957. In 1956, the hue of tree-harvested prunes ranged mostly between $4 \mathrm{Y}$ and $3 \mathrm{Y}$, as compared to $6 \mathrm{Y}$ and $5 \mathrm{Y}$ for tagged fruit during the same year. The differences were even greater in 1957, with prunes from the harvest tests ranging from $3 \mathrm{Y}$ to $10 \mathrm{YR}$, as compared to tagged fruit ranging from $5 \mathrm{Y}$ to $3 \mathrm{Y}$.

The cause of the greater variation in 1957 was more variability between orchards in different producing areas, possibly because of the warmer season. There is less yellow and more red in the commercially-harvested lots because the riper, more amber, fruits are selectively removed by light shaking. There is no consistent change in hue with harvest date, because selective 
harvesting results in quite similar maturity at each harvest. There may be little change in hue between the first and fourth harvest of the 4-harvest plots, save that differences are from a higher $\mathrm{Y}$ (yellow) to a lower Y (less yellow, more red). In the 2-harvest plots the reverse is often true. This may be explained by the 4-harvest pattern, which permits nearly all fruits to attain essentially the same maturity before harvest. In contrast, the second

TABLE 11

REFLECTANCE AND CHROMATICITY OF FRESH AND DEHYDRATED PRUNE FLESH (1957, TREE FRUIT)

\begin{tabular}{|c|c|c|c|c|c|c|c|}
\hline \multirow{3}{*}{ Orchard } & \multirow{3}{*}{ Harvest } & \multicolumn{3}{|c|}{ Fresh fruit flesh } & \multicolumn{3}{|c|}{ Dried fruit flesh } \\
\hline & & \multirow{2}{*}{$\underset{\mathrm{Y}}{\text { Reflectance }}$} & \multicolumn{2}{|c|}{ Chromaticity } & \multirow{2}{*}{$\underset{Y}{\text { Reflectance }}$} & \multicolumn{2}{|c|}{ Chromaticity } \\
\hline & & & $\mathbf{x}$ & $\mathrm{y}$ & & $\mathbf{x}$ & $\mathbf{y}$ \\
\hline \multirow{5}{*}{$\begin{array}{c}\text { Santa Clara } \\
\text { orchard } 6\end{array}$} & & per cent & & & per cent & & \\
\hline & $1 \ldots \ldots$ & 25.37 & 0.430 & 0.441 & 10.34 & 0.438 & 0.406 \\
\hline & & 26.65 & 0.444 & 0.446 & 10.60 & 0.445 & 0.415 \\
\hline & $3 \ldots$ & 22.18 & 0.453 & 0.445 & 9.65 & 0.445 & 0.412 \\
\hline & $4 \ldots \ldots \ldots \ldots$ & 16.47 & 0.457 & 0.443 & 9.08 & 0.430 & 0.390 \\
\hline \multirow{4}{*}{$\begin{array}{l}\text { Sonoma } \\
\text { orchard } 4\end{array}$} & $1 \ldots \ldots \ldots \ldots$ & 21.18 & 0.446 & 0.445 & 9.97 & 0.445 & 0.412 \\
\hline & $2 \ldots \ldots \ldots \ldots \ldots$ & 21.18 & 0.450 & 0.453 & 9.45 & 0.445 & 0.409 \\
\hline & $3 \ldots \ldots \ldots \ldots$ & 21.02 & 0.443 & 0.435 & 11.15 & 0.453 & 0.421 \\
\hline & $4 \ldots \ldots \ldots \ldots \ldots$ & 18.24 & 0.446 & 0.440 & 8.70 & 0.453 & 0.413 \\
\hline \multirow{3}{*}{$\begin{array}{l}\text { Napa } \\
\quad \text { orchard } 1\end{array}$} & $1 \ldots \ldots \ldots \ldots$ & 23.68 & 0.442 & 0.447 & 9.66 & 0.445 & 0.412 \\
\hline & $2 \ldots \ldots \ldots \ldots$ & 19.67 & 0.451 & 0.453 & 9.34 & 0.447 & 0.415 \\
\hline & $3 \ldots \ldots \ldots \ldots$ & 14.40 & 0.441 & 0.429 & 7.58 & 0.446 & 0.410 \\
\hline $\begin{array}{l}\text { Average for } \\
\text { all seven } \\
\text { orchards }\end{array}$ & & 21.1 & $\ldots \ldots$ & $\ldots \ldots$ & 9.41 & $\ldots$ & $\ldots$ \\
\hline
\end{tabular}

harvest of a 2-harvest pattern requires removal of fruits which may vary considerably in maturity.

Prunes that fell to the ground before a harvest nearly always had a lower $\mathrm{Y}$ than prunes shaken at that harvest. This would be expected on the assumption that riper fruits drop first. It is not known whether part of the more amber color should be assigned to climatic influences on the prunes after they had dropped. In some cases, reflectance of flesh is perceptibly less in dropped fruit than in tree fruit. This difference might well be due to fruit lying in the sun on the hot soil. Since coastal valley temperatures are usually not high the flesh color of fruit lying on the ground for a few days may not be perceptibly damaged.

The differences in hue of prunes between the two years is perhaps most strikingly shown in tables 8 and 9 . On the average the prunes were much more amber (less yellow, more red) in 1957 than in 1956. If color is related to firmness-another index of maturity-the prunes were firmer at harvest in 1957 than in 1956, and presumably less mature. On the other hand, harvest was later in 1957, soluble solids were substantially higher, the size of crop was smaller, and the average size of prunes was much larger. While no 
attempt is made to explain the differences between the two years, it is noted that seasonal differences are somewhat less in orchards 3 and 4 than in others, and also that differences in soluble solids, size of crop, and fruit size are somewhat less in these same orchards.

Tables 10 and 11 summarize data collected in three orchards, each in a different area. Fresh fruit was lighter in flesh color in 1956 than in 1957 in all of the orchards. The lightest fruits, in terms of reflectance, were found

TABLE 12

AVERAGE ACIDITY OF TREE-HARVESTED SAMPLES OF FRESH PRUNES FROM PLOTS IN 1956 AND 1957, EXPRESSED AS ml N/10 ALKALI TO TITRATE $10 \mathrm{ml}$ SLURRY TO $\mathrm{pH} 7$

\begin{tabular}{|c|c|c|c|c|c|c|c|c|c|}
\hline \multirow{3}{*}{ Year } & \multirow{3}{*}{$\begin{array}{l}\text { Number } \\
\text { of picks }\end{array}$} & \multicolumn{7}{|c|}{ Area and orchard } & \multirow{3}{*}{ Average } \\
\hline & & \multicolumn{2}{|c|}{ Napa } & \multicolumn{2}{|c|}{ Sonoma } & \multicolumn{3}{|c|}{ Santa Clara } & \\
\hline & & 1 & 2 & 3 & 4 & 5 & 6 & 7 & \\
\hline \multirow[t]{3}{*}{1956} & 4. & $\ldots$ & 2.1 & 2.2 & 1.6 & 1.7 & 1.8 & 1.7 & 1.85 \\
\hline & & 2.0 & 2.1 & 1.4 & 2.2 & 1.8 & 1.7 & 1.4 & 1.8 \\
\hline & & 2.2 & 2.6 & 1.4 & 2.7 & 2.3 & 3.1 & 2.4 & 2.3 \\
\hline \multirow[t]{3}{*}{1957} & 4. & 2.2 & 1.8 & 2.0 & 2.2 & 1.9 & 1.6 & 2.7 & 2.1 \\
\hline & 3. & 2.0 & 1.9 & 2.0 & 2.5 & 2.0 & 1.6 & 1.9 & 2.0 \\
\hline & $2 \ldots$ & 1.8 & 1.7 & 2.0 & 3.0 & 2.2 & 1.8 & 1.9 & 2.1 \\
\hline
\end{tabular}

in the earlier pickings, and the flesh darkened as the season advanced. The chromaticity values (mathematical expressions of hue and chroma) remained quite constant.

Flesh of dried prunes was lighter in 1957 than in 1956, in contrast to flesh of fresh fruit, as indicated by the average values obtained in all of the orchards and (with few exceptions) from the values obtained on individual harvest pickings. In 1956, fruit from the first and last pickings was darker than fruit from intermediate pickings. In 1957, darker fruit was generally from the last picking of the harvest. The cause of these differences is not known, but the delay of harvest in 1956 and the heavier crop that year (with resultant small size) may be a partial explanation of the darker dried fruit at the beginning and end of the harvest season. The 1957 crop was smaller, with larger fruits, and the soluble solids attained relatively high levels early, permitting harvest at a proper stage of maturity, so that the first picking produced dried fruit of a lighter color.

\section{Acidity and $\mathrm{pH}$}

Table 12 shows the average acidity of fresh prunes in relation to the number of harvests, and table 13 shows average acidity in relation to harvest sequence. There is some variation in acidity between orchards, number of harvests, and season, but variations are not consistent. In 1956, the 2-harvest plots were, with one exception, higher in acidity than the 3 or 4 -harvest lots; in 1957 there were no differences. The 1956 differences cannot be accounted for by harvest date (table 14) when compared to the 3-harvest plots. Whether 
the larger amount of fruit left on trees until late in the season influenced the acid content is not known, but it did not seem to influence the 1957 data. Differences in crop size may be a factor, however.

On the basis of averages, there is no difference in acidity between 1956 and 1957 , nor is there any notable difference between orchards, except possibly in orchard 4.

Table 13 shows that prunes collected from the tree at the last harvest are

TABLE 13

AVERAGE ACIDITY OF PRUNES IN RELATION TO

NUMBER OF PICKS AND HARVEST SEQUENCE,

EXPRESSED AS ml N/10 ALKALI TO TITRATE $10 \mathrm{ml}$

SLURRY TO $\mathrm{pH} 7$

\begin{tabular}{|c|c|c|c|}
\hline \multirow{2}{*}{$\begin{array}{l}\text { Number } \\
\text { of picks }\end{array}$} & \multirow{2}{*}{ Harvest } & \multicolumn{2}{|c|}{ Year } \\
\hline & & 1956 & 1957 \\
\hline \multirow[t]{4}{*}{4} & $1 \ldots \ldots \ldots \ldots$ & 2.1 & 2.5 \\
\hline & 2. & 1.3 & 1.8 \\
\hline & $3 \ldots$ & 1.4 & 1.9 \\
\hline & 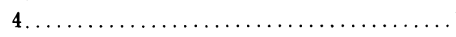 & 2.5 & 2.1 \\
\hline \multirow[t]{3}{*}{3} & $1 \ldots \ldots \ldots \ldots \ldots$ & 1.4 & 1.9 \\
\hline & $2 \ldots \ldots \ldots \ldots \ldots$ & 1.7 & 1.9 \\
\hline & 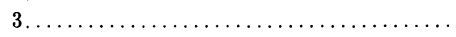 & 2.3 & 2.2 \\
\hline \multirow[t]{2}{*}{2} & 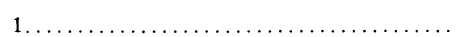 & 1.7 & 1.9 \\
\hline & 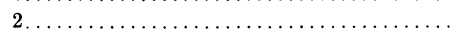 & 3.1 & 2.2 \\
\hline
\end{tabular}

a little higher in acid than prunes from previous harvests, except in the 4-harvest plots. This can be explained on the basis that at the final harvest all prunes are removed, whether fully mature or not. Usually, some prunesperhaps those in unfavorable positions for receiving elaborated food materials-are slow in maturing and are higher in acid. This delay in maturation is somewhat intensified by excessive cropping, such as occurred in 1956. The relatively high acidity in first-harvest fruits in the 4-harvest plots is probably due to a less advanced average maturity because of the earlier harvest date.

Differences in $\mathrm{pH}$ are comparable to differences in acidity. When the average is not weighted in relation to crop size, the average $\mathrm{H}^{+}$concentration, when converted to $\mathrm{pH}$ units, shows a difference between seasons of less than $0.1 \mathrm{pH}$ unit. Differences in $\mathrm{pH}$ of prunes between the number of harvests or between orchards are as much as $0.6 \mathrm{pH}$ unit, and those between harvests in a sequence may vary as much as $1.1 \mathrm{pH}$ units, although the average variation is much less than this.

\section{HARVEST PROCEDURE IN RELATION TO UNIFORMITY OF CROP REMOVAL AND PRUNES ON THE GROUND}

The number of harvests practical for coastal valley prunes may perhaps be best measured by the per cent of the crop removed at each harvest and the proportions from the tree and from the ground. Table 15 gives this informa- 
tion and table 14 gives the harvest dates. It seems doubtful that a grower could justify, from an economic standpoint, an early harvest that would remove only 10 to 12 per cent of the crop, unless such a procedure was imperative because of limited dehydrator capacity and the need for starting dehydration at an earlier date. It appears that in 1956 orchard 3 was harvested about a week too early in the 4-harvest sequence. This was also true of orchard 5, which had only 6 per cent of its crop collected in one harvest,

TABLE 14

HARVEST DATES OF PRUNE PLOTS

\begin{tabular}{|c|c|c|c|c|c|c|c|c|c|}
\hline \multirow{3}{*}{ Year } & \multirow{3}{*}{$\begin{array}{c}\text { Number } \\
\text { of } \\
\text { picks }\end{array}$} & \multirow{3}{*}{ Harvest } & \multicolumn{7}{|c|}{ Area and orchard } \\
\hline & & & \multicolumn{2}{|c|}{ Napa } & \multicolumn{2}{|c|}{ Sonoma } & \multicolumn{3}{|c|}{ Santa Clara } \\
\hline & & & 1 & 2 & 3 & 4 & 5 & 6 & 7 \\
\hline \multirow[t]{9}{*}{1956} & 4 & $1 \ldots$ & $\ldots$ & $8-16$ & $8-16$ & $8-22$ & $8-21$ & $8-20$ & $8-20$ \\
\hline & & $2 \ldots$ & $\ldots$ & $8-23$ & $8-22$ & $9-5$ & $8-27$ & $8-28$ & $8-28$ \\
\hline & & $3 \ldots$ & $\ldots$ & $8-30$ & $8-29$ & $9-12$ & $9-3$ & $9-3$ & $9-3$ \\
\hline & & & $\ldots$ & $9-13$ & $9-12$ & $9-18$ & $9-14$ & $9-15$ & $9-15$ \\
\hline & 3 & $1 .$. & $8-23$ & $8-23$ & $8-22$ & $9-5$ & $8-27$ & $8-28$ & $8-27$ \\
\hline & & & $8-30$ & $8-30$ & $8-29$ & $9-12$ & $9-3$ & $9-3$ & $9-3$ \\
\hline & & 3.. & $9-12$ & $9-6$ & $9-5$ & $9-18$ & $9-11$ & $9-10$ & $9-10$ \\
\hline & 2 & & $8-23$ & $8-23$ & $8-22$ & $9-5$ & $8-27$ & $8-27$ & $8-27$ \\
\hline & & $2 \ldots \ldots \ldots$ & $9-6$ & $9-6$ & $9-5$ & $9-12$ & $9-11$ & $9-10$ & $9-10$ \\
\hline \multirow[t]{9}{*}{1957} & 4 & $1 \ldots \ldots$ & $8-23$ & $8-19$ & $8-23$ & $9-3$ & $8-29$ & $8-22$ & $8-13$ \\
\hline & & $2 \ldots \ldots$ & $9-2$ & $8-26$ & $8-30$ & $9-10$ & $9-5$ & $8-29$ & $8-22$ \\
\hline & & $3 \ldots \ldots$ & $9-13$ & $9-3$ & $9-10$ & $9-20$ & $9-19$ & $9-11$ & $9-5$ \\
\hline & & $4 \ldots \ldots$ & $9-26$ & $9-16$ & $9-24$ & $10-2$ & $9-25$ & $9-19$ & $9-19$ \\
\hline & 3 & $1 \ldots \ldots \ldots \ldots \ldots \ldots$ & $8-26$ & $8-26$ & $8-27$ & $9-7$ & $9-5$ & $8-25$ & $8-22$ \\
\hline & & $2 \ldots \ldots \ldots \ldots \ldots$ & $9-7$ & $9-3$ & $9-6$ & $9-17$ & $9-11$ & $9-5$ & $8-28$ \\
\hline & & $3 \ldots \ldots \ldots \ldots \ldots$ & $9-23$ & $9-11$ & $9-20$ & $9-22$ & $9-25$ & $9-13$ & $9-13$ \\
\hline & 2 & $1 \ldots \ldots \ldots \ldots \ldots \ldots$ & $9-2$ & $8-30$ & $9-3$ & $9-13$ & $9-11$ & $8-28$ & $8-25$ \\
\hline & & $2 \ldots \ldots \ldots \ldots \ldots$ & $9-18$ & $9-9$ & $9-13$ & $9-24$ & $9-21$ & $9-11$ & $9-11$ \\
\hline
\end{tabular}

and 37 per cent of it collected 6 days later. The 2 -week interval between the first and second harvest in the 4-harvest sequence in orchard 4 would have resulted in a better distribution had the first harvest been delayed about a week; no doubt this would have reduced the ground drop of the second harvest.

In 1957, six of the seven first harvests in the 4-harvest sequence, and two of the seven harvests in the 3-harvest sequence, appear to have been too early (basing judgment upon the per cent of crop removed). Soluble solids content of the first-harvest prunes was high, indicating that the harvest was probably not too early. It seems more likely that the higher than normal temperatures resulted in prunes being attached more firmly than normal, and that a harder shake should have been used. 1957 was about a week later than 1956 in most areas, and this is reflected in all of the first harvest dates, except in orchard 7 where the first harvest was at least a week too early.

It is obvious that the harvest pattern was quite imperfect in many instances. For example, in 1956 in orchard 4, the interval between the first and last harvest was 27 days in the 4-harvest sequence, 13 days in the 3-har- 
vest, and 7 days in the 2-harvest. A more normal spacing might have been about 24,18 and 14 days, but such a harvest schedule was impossible because of shortage of help in collecting fruit from the widely spread areas. It is believed, however, that the information collected can be readily interpreted to show the most profitable harvesting practices. The first harvest could vary from a week to 10 days or more, depending on the number of harvests involved, and the part of the orchard harvested first could have one more harvest than the other part. Once begun, the grower would continue his harvest until it was complete.

The per cent of the crop on the ground under different harvesting procedures may influence the quality of the dried prunes, and will vary greatly between orchards and seasons. If soil temperatures are high enough to cause heat injury to the fresh fruit, the amount of damage will vary with the time fruits are at the high temperature. In some seasons in certain coastal valley areas fresh prunes apparently are not damaged by lying on the ground for several days-no doubt because ground temperatures are too low; in other seasons, flesh darkening is severe. The data in this study show a great variation in the amount of the crop on the ground, both between orchards and years. Usually, the per cent of the crop on the ground in any one orchard was quite closely related to the time interval between harvests, and therefore the 4-harvest plots could be expected to have less ground fruit than the 3 , and the 3 less than the 2 . The factor of harvest date would have to be considered also because of its relationship to maturity. In 1956, the amount of ground fruit was reasonably close to expectations. In 1957 there were some fairly wide discrepancies, as in orchard 4 . The variation between years is very great in orchard 2 and to a lesser degree in other instances, whereas in orchard 3 about 30 per cent of the prunes were on the ground each year. Fruit lying on the ground for a few days in this last orchard is usually not heat injured.

Dried Fruit Quality. The dried prune samples were graded for commercial acceptability by a panel of individuals familiar with commercial concepts of quality and marketability. The three grades established were as follows:

"A" Quality. Outside appearance: Whole-skinned and translucent; bright or "live" color.

Meat condition: Smooth, fine texture, clear light amber color.

"B" Quality. Outside appearance: Somewhat rough (finely wrinkled, or withered-looking skin), lacking in translucence, tending to be opaque.

Meat condition: Coarse texture, somewhat fibrous and porous, lacking in clear light amber color, tending to be darker or to have a greenish tinge.

"C" Quality. Outside appearance: Definitely rough skin, dull and variable in color.

Meat condition: Definitely fibrous, very coarse, permeated with prominent gas-pockets, very dark or definitely green in color. 


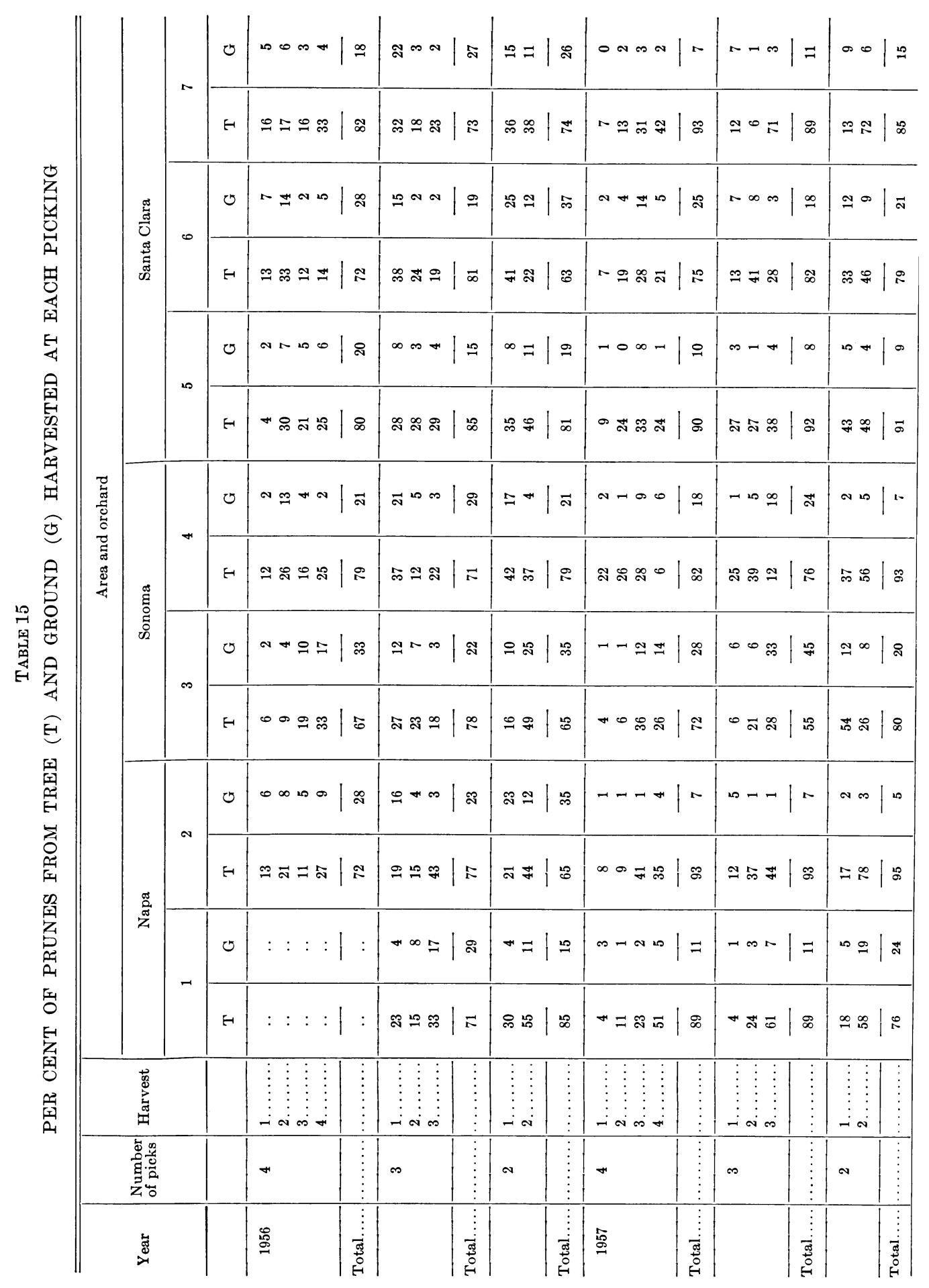


These qualities were used as a guide in this highly subjective type of grading. As the combinations of characteristics noted in the quality grades are many, the over-all grading must, of necessity, be relative and represent weighing of desirable against undesirable factors in a particular sample.

Samples from each orchard were graded independently, and grading

TABLE 16

QUALITY OF DRIED FRENCH PRUNES HARVESTED IN 1956 AND 1957

\begin{tabular}{|c|c|c|c|c|c|c|c|}
\hline \multirow{3}{*}{$\begin{array}{l}\text { Crop year and } \\
\text { area of } \\
\text { production }\end{array}$} & \multirow{3}{*}{ Harvest } & \multicolumn{6}{|c|}{ Fruit characteristics } \\
\hline & & \multicolumn{2}{|c|}{$\begin{array}{c}\text { Outside } \\
\text { appearance* }\end{array}$} & \multicolumn{2}{|c|}{$\begin{array}{c}\text { Flesh color } \\
\text { and condition* }\end{array}$} & \multicolumn{2}{|c|}{$\begin{array}{l}\text { Number and size of } \\
\text { gas pockets ( } 25 \text { fruits }) \dagger\end{array}$} \\
\hline & & Tree & Ground & Tree & Ground & Tree & Ground \\
\hline $\begin{array}{l}\text { 1956: } \\
\text { Napa } \\
\text { orchard } 1\end{array}$ & $\begin{array}{l}1 \ldots \ldots \ldots \ldots \\
2 \ldots \ldots \ldots \ldots \ldots \ldots \ldots \\
3 \ldots \ldots \ldots \ldots \ldots\end{array}$ & $\begin{array}{l}\text { A } \\
\text { A } \\
\text { A }\end{array}$ & $\begin{array}{l}\text { A } \\
\text { A } \\
\text { A }\end{array}$ & $\begin{array}{l}\mathrm{A}- \\
\mathrm{A} \\
\mathrm{A}\end{array}$ & $\begin{array}{l}\mathrm{A}- \\
\mathrm{A} \\
\mathrm{A}\end{array}$ & $\begin{array}{l}4 \mathrm{~L} \\
4 \mathrm{~m}, 4 \mathrm{~L} \\
8 \mathrm{~m}, 4 \mathrm{~L}\end{array}$ & $\begin{array}{l}2 \mathrm{~s}, 2 \mathrm{~m}, 2 \mathrm{~L} \\
4 \mathrm{~s}, 8 \mathrm{~m} \\
4 \mathrm{~s}, 4 \mathrm{~m}, 4 \mathrm{~L}\end{array}$ \\
\hline $\begin{array}{l}\text { Sonoma } \\
\text { orchard } 3\end{array}$ & $\begin{array}{l}1 \ldots \ldots \ldots \\
2 \ldots \ldots \ldots \\
3 \ldots \ldots \ldots\end{array}$ & $\begin{array}{l}\mathrm{A} \\
\mathrm{A} \\
\mathrm{A}\end{array}$ & $\begin{array}{l}\mathrm{A} \\
\mathrm{A} \\
\mathrm{A}\end{array}$ & $\begin{array}{l}\mathrm{A} \\
\mathrm{A} \\
\mathrm{A}\end{array}$ & $\begin{array}{l}\mathrm{A} \\
\mathrm{A} \\
\mathrm{A}\end{array}$ & $\begin{array}{l}2 \mathrm{~s} \\
4 \mathrm{~m}, 4 \mathrm{~L} \\
\text { None }\end{array}$ & $\begin{array}{l}2 \mathrm{~m} \\
4 \mathrm{~m} \\
\text { None }\end{array}$ \\
\hline $\begin{array}{l}\text { Santa Clara } \\
\text { orchard } 6\end{array}$ & $\begin{array}{l}1 \ldots \ldots \ldots \\
2 \ldots \ldots \ldots \ldots \\
3 \ldots \ldots \ldots\end{array}$ & $\begin{array}{l}\mathrm{A} \\
\mathrm{A} \\
\mathrm{B}\end{array}$ & $\begin{array}{l}\text { A } \\
\text { B } \\
\text { A }\end{array}$ & $\begin{array}{l}\mathrm{A} \\
\mathrm{A} \\
\mathrm{A}-\end{array}$ & $\begin{array}{l}\mathrm{A}- \\
\mathrm{A}- \\
\mathrm{A}\end{array}$ & $\begin{array}{l}2 \mathrm{~L} \\
4 \mathrm{~m}, 2 \mathrm{~L} \\
2 \mathrm{~L}\end{array}$ & $\begin{array}{l}4 \mathrm{~m}, 6 \mathrm{~L} \\
2 \mathrm{~m}, 6 \mathrm{~L} \\
6 \mathrm{~s}, 2 \mathrm{~m}\end{array}$ \\
\hline $\begin{array}{l}\text { 1957: } \\
\text { Napa } \\
\text { orchard } 1\end{array}$ & 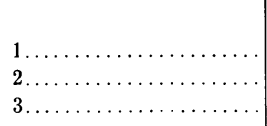 & $\begin{array}{l}\mathrm{A} \\
\mathrm{A}- \\
\mathrm{A}-\end{array}$ & $\begin{array}{l}\text { A } \\
\text { A } \\
\text { B }\end{array}$ & $\begin{array}{l}\mathrm{A}- \\
\mathrm{A} \\
\mathrm{B}-\end{array}$ & $\begin{array}{l}\mathrm{D}+ \\
\mathrm{A}- \\
\mathrm{C}+\end{array}$ & $\begin{array}{l}6 \mathrm{~s}, 1 \mathrm{~m}, 1 \mathrm{~L} \\
8 \mathrm{~s}, 2 \mathrm{~L} \\
2 \mathrm{~s}, 5 \mathrm{~m}, 4 \mathrm{~L}\end{array}$ & $\begin{array}{l}6 \mathrm{~s}, 2 \mathrm{~m}, 3 \mathrm{~L} \\
2 \mathrm{~s}, 5 \mathrm{~m}, 2 \mathrm{~L} \\
5 \mathrm{~s}, 2 \mathrm{~m}, 7 \mathrm{~L}\end{array}$ \\
\hline $\begin{array}{l}\text { Sonoma } \\
\text { orchard } 3\end{array}$ & 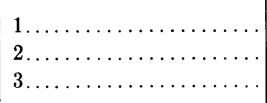 & $\begin{array}{l}\mathrm{A}- \\
\mathrm{A} \\
\mathrm{A}\end{array}$ & $\begin{array}{l}\text { A } \\
\text { A } \\
B-\end{array}$ & $\begin{array}{l}\mathrm{A}- \\
\mathrm{A} \\
\mathrm{C}-\end{array}$ & $\begin{array}{l}\mathrm{A} \\
\mathrm{A}- \\
\mathrm{A}-\end{array}$ & $\begin{array}{l}3 \mathrm{~s}, 1 \mathrm{~m}, 1 \mathrm{~L} \\
4 \mathrm{~s}, 1 \mathrm{~m} \\
2 \mathrm{~s}, 3 \mathrm{~m}, 5 \mathrm{~L}\end{array}$ & $\begin{array}{l}3 \mathrm{~s}, 1 \mathrm{~m}, 5 \mathrm{~L} \\
5 \mathrm{~s}, 8 \mathrm{~m}, 3 \mathrm{~L} \\
2 \mathrm{~s}, 3 \mathrm{~m}, 5 \mathrm{~L}\end{array}$ \\
\hline $\begin{array}{l}\text { Santa Clara } \\
\text { orchard } 6\end{array}$ & $\begin{array}{l}1 \ldots \ldots \ldots \ldots \ldots \ldots \ldots \\
2 \ldots \ldots \ldots \ldots \ldots \ldots \ldots \\
3 \ldots \ldots \ldots \ldots \ldots \ldots \ldots \ldots\end{array}$ & $\begin{array}{l}\mathrm{A} \\
\mathrm{A} \\
\mathrm{B}+\end{array}$ & $\begin{array}{l}\mathrm{B}- \\
\mathrm{B}+ \\
-\end{array}$ & $\begin{array}{l}\mathrm{D}+ \\
\mathrm{A}- \\
\mathrm{B}+\end{array}$ & $\begin{array}{l}\mathrm{A}- \\
\mathrm{B} \\
-\end{array}$ & $\begin{array}{l}3 \mathrm{~s}, 3 \mathrm{~m}, 1 \mathrm{~L} \\
3 \mathrm{~s}, 2 \mathrm{~m}, 5 \mathrm{~L} \\
6 \mathrm{~s}, 1 \mathrm{~m}, 7 \mathrm{~L}\end{array}$ & $\begin{array}{l}3 \mathrm{~s}, 7 \mathrm{~m}, 1 \mathrm{~L} \\
4 \mathrm{~s}, 3 \mathrm{~m}, 7 \mathrm{~L} \\
\quad \ldots \ldots\end{array}$ \\
\hline
\end{tabular}

* Subjectively graded on physical appearance of prunes, where $\mathrm{A}$ has the most desirable characteristics and $D$ the least desirable.

$t \mathrm{~s}=$ small gas pockets, which give spongy appearance to meat; $\mathrm{m}=$ medium gas pockets, about $1 \mathrm{~mm}$ diameter; $\mathrm{L}=$ large gas pockets, about $2 \mathrm{~mm}$ diameter or larger. In 1957 , cuts were made on both sides of pit (as compared with only one side in 1956), thus exposing gas pockets in more fruits and resulting in higher counts in 1957.

emphasis was placed on the characteristics influenced primarily by maturity-that is, bird-pecked fruit, etc., were disregarded.

Grading in this manner resulted in most of the samples being regarded as "A" quality fruit in both the 1956 and 1957 crop years. Table 16 shows the results of grading fruit by individual orchards from three different areas, and compares the tree and ground samples of the various pickings from the 3-harvest plots on an " $A$ " quality working basis. Data collected on samples from the 4-harvest plots and the 2-harvest plots are in agreement with those shown in table 16. The 2-harvest plot samples average very slightly lower in quality, but this difference is believed to result from the fact that the trees were shaken harder on the first picking. As a result of 
this, the fruit collected from both pickings contained a greater variation in degree of fruit maturity than was the case with fruit removed in 3 or 4 harvests. In addition, the second harvest contained more fruit that had not attained full maturity.

Examination of the data shows certain general trends (though it should be noted that there are exceptions to them): (1) Samples harvested early and samples harvested last were somewhat lower in quality than fruit harvested in mid-season. In early samples the primary factors in lowering quality were poor skin color and greenish flesh, and some samples also contained gas pockets. Since all remaining fruit was removed at the last harvest, some immature fruit was included. Dark-colored flesh and gas pockets were also evident. (2) Fruits included in the ground samples were generally of slightly lower quality than the corresponding fruits harvested from the tree in 1956. The small differences primarily involved color and meat texture, and probably are due to different climatic conditions prevailing in the three areas. Orchard 3 has a pronounced coastal climate (cool and higher humidity) and heat injury to the fruit on the ground therefore is minimized. The climate at orchard 1 is nearly that of the interior valley, and ground fruit there shows more heat injury than fruits from the other orchards. The quality of fruit from orchard 6 reflects the intermediate climatic conditions found in coastal areas. Both 1956 and 1957 were relatively cool years, at least during the harvest season, and heat injury is thus less than might be expected. The amount of fruit spontaneously falling to the ground was less during 1957 and thus there often were not enough ground samples for drying and grading. (3) The quality of prunes collected was better in 1956 than in 1957, although the prunes were smaller in 1956.

There is some evidence that larger prunes (and other fruits) are more susceptible to heat injury on the tree than are smaller prunes (Maxie and Claypool, 1957). This conclusion is based on the smaller surface-to-volume ratio of larger fruits, and on the fact that oxygen, necessary for normal respiration, must diffuse through the skin into the flesh. Under conditions that might favor heat injury, the rate of respiration (and the demand for oxygen) is increased. In the deep tissues of a large fruit, oxygen becomes a limiting factor and an anaerobic condition arises which leads to fermentation and the production of carbon dioxide. If anaerobiosis continues long enough it may be lethal to many cells, and as a result the quality of the prune is lowered by darkening of the flesh and the formation of voids (which appear as gas pockets in the dried product).

Prunes harvested in the coastal valleys in 1956 and 1957 were not substantially different in quality as a result of frequency of harvest or lying on the ground. Minor differences existed in the plots with 2, 3, and 4 harvests, as well as between tree and ground fruit.

Fruit quality of the early harvest is affected by the inclusion of fruits dropping to the ground before harvest, or by fruits that are easily removed from the tree with a very light shaking. Such fruits are often defective, and probably would never develop into high-grade fruit; this elimination would very likely improve the overall quality. Table 16 shows the number and sizes of gas pockets found in dried prunes, and also shows the quality grades 
given the dried fruit samples; data are similar to those obtained by 2 and 4 harvests. Since gas pockets were only one of the several factors influencing the quality of the prune flesh, there is no correlation between the two. Generally, however, large gas pockets were more common in ground samples and in the lower quality grades, particularly in fruit harvested late. Gas pockets are most noticeable in the dried fruit; in processed prunes the smaller gas

TABLE 17

REHYDRATION RATES OF VARIOUS SIZES OF DRIED

PRUNES FROM VARIOUS PRUNE-PRODUCING AREAS

OF CALIFORNIA, 1956-1957

\begin{tabular}{|c|c|c|}
\hline Size & \multicolumn{2}{|c|}{ Rehydration rate* } \\
\hline (Count per pound) & Average & Range \\
\hline $101-110$. & 9.23 & $7.50-11.25$ \\
\hline $91-100$. & 8.94 & $8.00-10.50$ \\
\hline $81-90 \ldots$ & 8.70 & $6.00-12.50$ \\
\hline $71-80 \ldots \ldots$ & 8.36 & $6.25-11.50$ \\
\hline $61-70 \ldots \ldots \ldots$ & 8.18 & $5.55-11.50$ \\
\hline $51-60 \ldots \ldots \ldots \ldots \ldots \ldots \ldots \ldots \ldots$ & 6.54 & $4.75-10.33$ \\
\hline
\end{tabular}
fruit.

* Rehydration rate expressed as grams of water gained per minute per pound of dried

pockets are less apparent, but tend to give the flesh a porous appearance. Larger gas pockets are pronounced in both dry and processed fruits.

The rate at which water is taken up by dried prunes during processing was determined, and weight gain from immersion in hot water $\left(210-212^{\circ} \mathrm{F}\right)$ for repeated time intervals was plotted against the time of immersion (up to 10 minutes). The slope of the resulting plot determined the rate of rehydration.

Analysis of the data obtained in 1956 and 1957 showed no correlation between rate of rehydration and initial moisture content or the soluble solids of the dried fruit. A correlation could be found only with the size of the fruit (count per pound). Table 17 shows that average rehydration rate increased as average count per pound increased. The range of rehydration rates shows that, within the size divisions, the maximum rates are similar. The minimum rates generally have the same trend as the average rates.

It was found that samples taken from the trees or the ground within a particular orchard also had increasing rehydration rates as the count per pound increased. Fruit having the same count per pound from different orchards and in different areas of production had different rehydration rates, however. The results of the present study are in accord with those of Nichols (1935).

\section{ORGANOLEPTIC EVALUATION OF DRIED PRUNES}

Sensory tests on dried fruit were made by a panel of judges selected for consistent discrimination in evaluating prunes of varying quality.

In 1956, prunes harvested by a light shaking of the tree were compared with spontaneously fallen ground fruit. The samples were collected in three 
orchards, representing the three areas under study. Table 18 shows comparisons in flavor and texture for the 4-harvest plots. Nearly half of the tests resulted in a significant number of judges being unable to detect any differences in texture between the paired samples.

The judges discriminated to a high degree between the flavor of paired samples, although in only one case (orchard 3, 4th picking, ground fruit) was there a significant preference for one of the pair (table 18). Examina-

TABLE 18

ORGANOLEPTIC EVALUATION FOR PREFERENCE OF FLAVOR AND TEXTURE OF PRUNES DRIED FROM FRUIT COLLECTED FROM TREE AND FROM GROUND (FOUR PICKINGS, 1956)

\begin{tabular}{|c|c|c|c|c|c|c|}
\hline \multirow{3}{*}{ Series } & \multicolumn{6}{|c|}{ Orchard and area } \\
\hline & \multicolumn{2}{|c|}{2 (Sonoma) } & \multicolumn{2}{|c|}{3 (Sonoma) } & \multicolumn{2}{|c|}{7 (Santa Clara) } \\
\hline & Flavor & Texture & Flavor & Texture & Flavor & Texture \\
\hline Number of judgments.. & 18 & 18 & 20 & 20 & 6 & 6 \\
\hline No difference* ${ }^{*} . \ldots \ldots \ldots$ & $4 \dagger$ & $15 \ddagger$ & $1 \S$ & 14 & 0 & 3 \\
\hline First pick: Tree..... & 11.0 & 8.5 & 13.5 & 11.0 & 6.0 & 4.5 \\
\hline Ground... & 7.0 & 9.5 & 6.5 & 9.0 & 0.0 & 1.5 \\
\hline Number of judgments............. & 20 & 20 & 14 & 14 & 8 & 8 \\
\hline No difference................ & $2 \S$ & 14 & $1 \ddagger$ & 10 & 1 & 7 \\
\hline Second pick: Tree........... & 12.0 & 10.0 & 5.5 & 7.0 & 4.5 & 4.5 \\
\hline Ground $\ldots \ldots \ldots \ldots$ & 8.0 & 10.0 & 8.5 & 7.0 & 3.5 & 3.5 \\
\hline Number of judgments............ & 16 & 16 & 19 & 19 & 7 & 7 \\
\hline No difference................... & $2 \ddagger$ & $13 \ddagger$ & $3 \ddagger$ & 13 & 2 & 5 \\
\hline Third pick: Tree............... & 6.0 & 7.0 & 5.5 & 8.5 & 3.0 & 2.5 \\
\hline Ground.............. & 10.0 & 9.0 & 13.5 & 10.5 & 4.0 & 4.5 \\
\hline Number of judgments.......... & 16 & 16 & 19 & 19 & 8 & 8 \\
\hline No difference.................. & $1 \S$ & $12 \ddagger$ & $0 \S$ & $15 \ddagger$ & $0 \ddagger$ & 5 \\
\hline Fourth pick: Tree............... & 6.5 & 8.0 & 3.0 & 8.5 & 2.0 & 4.5 \\
\hline Ground.............. & 9.5 & 8.0 & $16.0 \ddagger$ & 10.5 & 6.0 & 3.5 \\
\hline
\end{tabular}

* Significance noted both directions.

† 0.05 probability level.

0.01 probability level.

$\$ 0.001$ probability level.

tion of data collected on the fresh fruit samples shows that this particular harvest removed 50 per cent of the total fruit harvested from the plot. Of the fruit harvested at that time two-thirds was removed from the tree, and consequently the range of fruit maturity in this last picking could be wide, and thus include fruit that had not reached full maturity. This is in contrast to the ground sample, which would be expected to be composed primarily of fully mature fruit. This orchard has very coastal climatic conditions, and heat injury to ground fruit is minimal. Had there been heat injury to the fruit it is reasonable to assume that it would have impaired the flavor rating of the sample.

The judges tended to prefer the tree sample to the ground sample in the first picking; the ground sample would include defective fruits and those that dropped to the ground before the first light shaking of the tree. The 
tree fruit removed by the first light shake would be expected to contain primarily the fruits that were mature and ready to be harvested. Fruit that fell to the ground after the first picking, as well as the second and third tree samples, should contain all mature fruit. This is reflected in the preferences of the judges in 1956, which do not show much difference in flavor between tree and ground samples in the harvests after the first harvest (excluding the one exception previously discussed). In 1957, the crop was relatively

TABLe 19

ORGANOLEPTIC EVALUATION FOR PREFERENCE OF FLAVOR AND

TEXTURE OF PRUNES DRIED FROM FRUIT COLLECTED FROM TREE AND FROM GROUND (THREE PICKINGS, 1957)

\begin{tabular}{|c|c|c|c|c|c|c|}
\hline \multirow{3}{*}{ Series } & \multicolumn{6}{|c|}{ Orchard and area } \\
\hline & \multicolumn{2}{|c|}{1 (Napa) } & \multicolumn{2}{|c|}{3 (Sonoma) } & \multicolumn{2}{|c|}{6 (Santa Clara) } \\
\hline & Flavor & Texture & Flavor & Texture & Flavor & Texture \\
\hline Number of judgments.. & 23 & 23 & 30 & 30 & 19 & 19 \\
\hline No difference*.................. & $0 \dagger$ & $5^{*}$ & $3 \dagger$ & 10 & $3 \ddagger$ & 9 \\
\hline First pick: Tree $\ldots \ldots \ldots \ldots \ldots \ldots$ & 14 & 12.5 & 15.5 & 15 & 14.5 & 12.5 \\
\hline Ground.......... & 9 & 10.5 & 14.5 & 15 & 4.5 & 6.5 \\
\hline Number of judgments............. & $\ldots$ & $\ldots$ & 30 & 30 & 19 & 19 \\
\hline No difference............... & $\ldots$ & $\ldots$ & $3 \dagger$ & 13 & $4 \S$ & 11 \\
\hline Second pick: Tree...... & $\ldots$ & $\ldots$ & 18.5 & 16.5 & $13 \S$ & 11.5 \\
\hline Ground... & $\ldots$ & $\ldots$ & 11.5 & 13.5 & 6 & 7.5 \\
\hline Number of judgments. . & 23 & 23.0 & 30 & 30 & $\ldots$ & $\ldots$ \\
\hline No difference........ & $2 \dagger$ & 11.0 & $5 \dagger$ & 13 & $\ldots$ & $\ldots$ \\
\hline Third pick: Tree. & 16 & 14.5 & 16.5 & 13.5 & $\ldots$ & $\ldots$ \\
\hline Ground. & 7 & 8.5 & 13.5 & 16.5 & $\ldots$ & $\ldots$ \\
\hline
\end{tabular}

* Significance noted both directions.

† 0.001 probability level.

$\$ 0.01$ probability level.

$\$ 0.05$ probability level.

light in most orchards, with less fruit in the ground samples. Table 19 shows results from 3-harvest plots in 1957, since ground samples were insufficient in the 4-harvest plots. As in 1956, the judges were able to significantly detect differences between paired samples, and the trends, though not at a significant level, indicated preference for the flavor of tree samples over that of the ground samples.

The effect of multiple harvests on the quality of the fruit removed from the tree at any one harvest was studied in 1956 by subjecting samples of prunes to organoleptic evaluation. This test was made on fruit from the 4-harvest plots from one orchard from each of the three areas. Table 20 summarizcs the results. Because the orchards had relatively heavy crops and small fruits with lower soluble solids in 1956, multiple harvests might be expected to have a beneficial effect on the quality of the fruit harvested later, and data indicate that this is generally the case. Table 20 also shows the effects of climate in the area. In orchard 3 (which has the most coastal type of climate) judges were able to evaluate the tree fruit of the first picking 
as less desirable in flavor, and the fruit of the third picking as most desirable. In orchard 7 (intermediate climate) the only significant evaluation was the preference for the flavor of the third-pick fruit. In orchard 2 the trend was the same, though the differences were not significant. The preference for

TABLE 20

EFFECT OF PICKING 4 TIMES ON PRUNE FLAVOR AND TEXTURE QUALITY OF TREE-HARVESTED LOTS IN 1956 (Expressed as

Percentage of Judgments, and Attributing Better Flavor and Texture to the Sample)

\begin{tabular}{|c|c|c|c|}
\hline \multirow{2}{*}{ Series } & \multicolumn{3}{|c|}{ Orchard and area } \\
\hline & 2 (Sonoma) & 3 (Sonoma) & 7 (Santa Clara) \\
\hline \multicolumn{4}{|l|}{ First pick: } \\
\hline Number of judgments. & 54 & 60 & 63 \\
\hline Flavor............. & 44.4 & $24.2^{*}$ & 38.1 \\
\hline 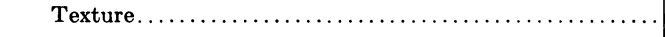 & 48.2 & 42.5 & 44.5 \\
\hline \multicolumn{4}{|l|}{ Second pick: } \\
\hline Number of judgments........................... & 58 & 48 & 54 \\
\hline 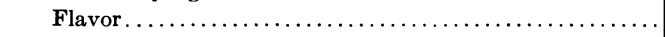 & 45.6 & 53.1 & 42.6 \\
\hline 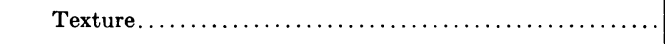 & 48.3 & 53.1 & 50.0 \\
\hline \multicolumn{4}{|l|}{ Third pick: } \\
\hline Number of judgments.. & 58 & 48 & 70 \\
\hline 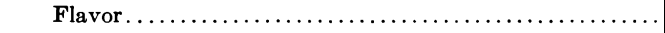 & 57.8 & $74.0 \dagger$ & $71.4^{*}$ \\
\hline 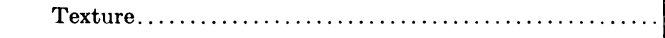 & 52.6 & 56.3 & 53.7 \\
\hline \multicolumn{4}{|l|}{ Fourth pick: } \\
\hline Number of judgments. & 58 & 48 & 63 \\
\hline 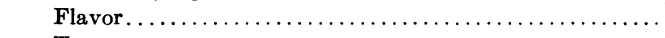 & 51.7 & 55.2 & 46.0 \\
\hline 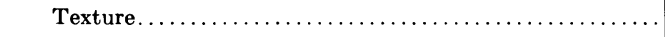 & 50.0 & 50.0 & 53.2 \\
\hline
\end{tabular}

* Significantly better or worse at 0.001 probability level.

† Significantly better or worse at 0.01 probability level.

fruit from the third pick over fruit from the fourth pick is believed to reflect the fourth-pick practice of removing all remaining fruit from the tree.

Results of the organoleptic evaluations generally correlated well with the information collected on the fresh prunes.

\section{Storage of Fresh Prunes Before Dehydration}

In some years rain falls during the prune harvest season, damaging the remaining crop severely. It has been thought that many prunes might be saved by cold storage where rate of harvest is controlled by dehydrator capacity. Also, prunes sometimes remain in boxes for several days before being dehydrated because of insufficient dehydrator capacity. Thus, it seemed desirable to determine the effect of storage on the quality of the dehydrated product.

In 1956, lots of prunes were collected for storage studies from orchard 1 , in Napa County, and the University of California orchard at Davis. These prune lots were divided into three sublots as follows: Sublot 1 was dehydrated on the day the fruit was harvested, or on the following day after storage at $32-34^{\circ} \mathrm{F}$; sublot 2 was held in the shade at outside temperatures 
in the boxes for three days before being dehydrated; sublot 3 was held 30 days at $32-34^{\circ} \mathrm{F}$ before being dehydrated.

In 1957, the study was repeated with fruit from the same two orchards, but with some additional variables. Prunes from all lots were harvested on

TABLE 21

EFFECT OF COLD STORAGE OF FRESH PRUNES ON MOLDING AND ON DRIED FRUIT QUALITY

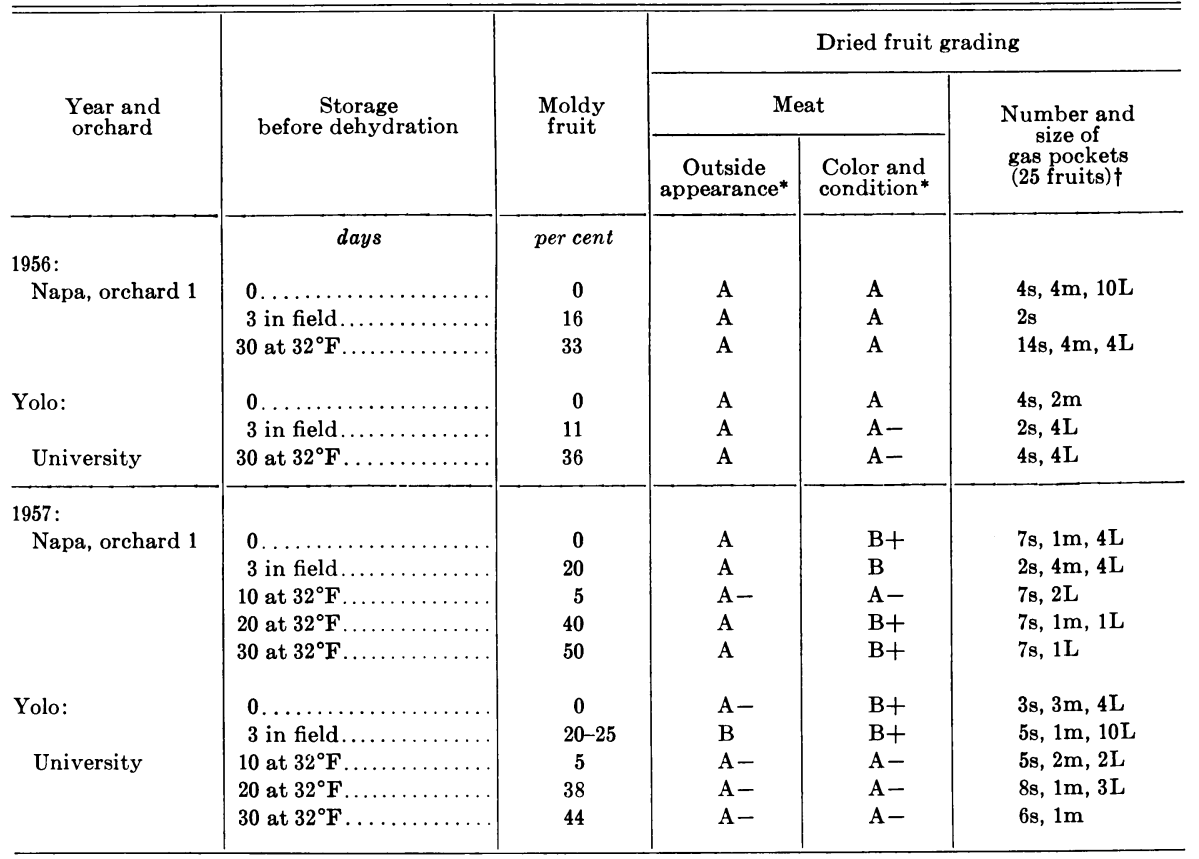

* Subjectively graded on physical appearance of prunes, where A has the most desirable characteristics and $D$ the least desirable.

† $\mathrm{s}=$ small gas pockets which give spongy appearance to meat; $\mathrm{m}=$ medium gas pockets, about $1 \mathrm{~mm}$ diameter: $\mathrm{L}=$ large gas pockets, about $2 \mathrm{~mm}$ diameter or larger. In 1957, cuts were made on both sides of pit (as compared with only one side in 1956), thus exposing gas pockets in more fruits and resulting in higher counts in 1957.

September 2. Sublot 1, the control lot, was dehydrated on the day following harvest, after overnight cold storage. Sublot 2 was redivided so that half of the fruit was dehydrated on the third day after harvest and held in boxes in the shade at outside temperatures, and the other half was dehydrated on the fifth day after harvest. Sublot 3 was divided three ways, so that dehydration was begun 10,20 , and 30 days after storage at $32-34^{\circ} \mathrm{F}$.

The results showed that field storage is impractical and that cold storage $\left(32-34^{\circ} \mathrm{F}\right)$ longer than 10 days is infeasible because of the great losses of fruit from mold. Table 21 shows the results of fresh fruit analyses for 1956 and 1957. In 1956, all of the storage samples had excessive losses from mold. In 1957, only the sample stored for 10 days had losses small enough that postharvest storage might be considered.

When samples of the carefully sorted sound fruit were dehydrated and graded, the quality grades showed little differences between the various 
treatments. Fruit from both orchards was of a better quality in 1956 than in 1957 (external appearance and flesh color and condition). These findings agree with the results obtained in the other orchards included in this study. It must be remembered, however, that these samples were thoroughly sorted for defective and spoiled fruits and do not represent the original samples.

Organoleptic evaluation of the dried samples (table 22) showed no signifi-

TABLE 22

PERCENTAGE OF JUDGMENTS ATTRIBUTING BETTER FLAVOR AND TEXTURE TO PRUNES DRIED AFTER VARYING POSTHARVEST PERIODS

\begin{tabular}{|c|c|c|c|c|c|c|c|}
\hline \multirow{3}{*}{ Location } & \multirow{3}{*}{$\begin{array}{c}\text { Storage before } \\
\text { dehydration }\end{array}$} & \multicolumn{6}{|c|}{ Year } \\
\hline & & \multicolumn{3}{|c|}{1956} & \multicolumn{3}{|c|}{1957} \\
\hline & & $\begin{array}{c}\text { Number } \\
\text { of } \\
\text { judg- } \\
\text { ments* }\end{array}$ & Flavor & Texture & $\begin{array}{c}\text { Number } \\
\text { of } \\
\text { judg- } \\
\text { ments* }\end{array}$ & Flavor & Texture \\
\hline & days & & per cent & per cent & & per cent & per cent \\
\hline \multirow[t]{3}{*}{ Napa County } & $0 \ldots \ldots \ldots$ & 36 & 51.4 & 54.2 & 94 & 52.5 & 49.7 \\
\hline & 3 in field.. & 36 & 52.9 & 48.7 & 96 & 51.7 & 51.6 \\
\hline & 10 at $32^{\circ} \mathrm{F}$. & .. & $\ldots$ & $\ldots$ & 94 & 46.5 & 59.8 \\
\hline \multirow[t]{2}{*}{ (Rutherford) } & 20 at $32^{\circ} \mathrm{F}$. & . & $\ldots$ & $\ldots$ & 95 & 55.8 & 43.5 \\
\hline & 30 at $32^{\circ} \mathrm{F}$. & 36 & 45.8 & 47.2 & 91 & 43.1 & 45.4 \\
\hline \multirow[t]{3}{*}{ Yolo County } & $0 \ldots \ldots$ & 52 & 37.5 & 44.2 & 95 & 53.6 & 53.3 \\
\hline & 3 in field.. & 52 & 48.1 & 50.0 & 95 & 29.0 & 35.6 \\
\hline & 10 at $32^{\circ} \mathrm{F}$. & .. & $\ldots$ & $\ldots$ & 94 & 59.2 & 66.0 \\
\hline \multirow[t]{2}{*}{ (Davis) } & 20 at $32^{\circ} \mathrm{F} \ldots \ldots \ldots \ldots$ & .. & $\ldots$ & $\ldots$ & 100 & 62.5 & 51.1 \\
\hline & 30 at $32^{\circ} \mathrm{F} \ldots \ldots$ & 52 & 64.5 & 55.8 & 98 & 45.9 & 43.9 \\
\hline
\end{tabular}

* Number of judgments comparing that sample with other samples offered in paired comparisons.

cant detectable differences in flavor in 1956. In 1957, fruit from the University orchard, which had been stored at outside temperatures in the shade, were not preferred. Texture differences were not significant for any of the samples collected in the two years.

\section{DISCUSSION AND CONCLUSIONS}

On the basis of tagged fruit lots (Claypool, Dempsey, Esau, and Miller, 1962) the average firmness of prunes on the tree when harvest was begun was between 3.0 and 3.5 pounds in 1956, and between 4.0 and 4.5 pounds in 1957 . The firmness of prunes that dropped to the ground in the first shaking, however, averaged only 0.8 pounds in 1956 and 1.5 pounds in 1957 . Soluble solids were low in 1956 because of an excessively heavy crop in most orchards, and were high in 1957. In both seasons, the prunes harvested from the trees were of good color and quality when dried. The first and last harvests were a little poorer than others, particularly in the heavy-crop year. Defective fruits are usually collected in the first harvest, and the last harvest includes all remaining fruits, which in a heavy-crop year includes many that are poorly supplied with carbohydrate materials and some that have not reached full maturity. 
Flesh color and firmness are suitable maturity indexes (Claypool, Dempsey, Esau, and Miller, 1962). Soluble solids content is a useful index, but may vary greatly with size of crop. In a normal or light crop year (such as 1957) when the green color has disappeared from the flesh and average flesh firmness of fruit on the tree has dropped to about 3.0 pounds the soluble solids content will equal, or exceed, 24 per cent. When selective harvesting is practiced, as in the coastal valleys, the soluble solids content of the fruit that falls with a light shake will exceed this figure. In heavily cropped orchards (as in 1956) the prunes may be ready for harvest at a much lower soluble solids content. In this situation, prunes selectively harvested will have higher soluble solids content than the average for the tree.

Properly timed selective harvesting in three pickings resulted in as good dried fruit quality and yields as harvesting in four pickings. A 4-pick harvest may have an advantage, however, in a heavy crop year by extending the period of dehydrator operation. This is particularly true in the coastal areas, where the fruit readily drops to the ground when fully mature. In seasons in which some areas are intermediate between coastal and interior valley climatic conditions, and where the fruit does not drop readily when mature, two harvests may be adequate if dehydrator capacity is not a problem.

Fruit that dropped naturally to the ground was not damaged in quality or flavor if temperatures were not high enough to cause heat injury. Heat injury can vary greatly from year to year and is determined by the microclimate of the orchard during the harvest season; it is not usually a serious problem in coastal areas. In these tests no injury was noted in 1956, but in 1957 injury occurred in orchards that experienced increased temperatures in their microclimates. No doubt the large fruit size in 1957 was a factor.

Quality grading of the dried fruit is so highly subjective that it is difficult to determine differences closely related to those observed in the fresh fruit. Differences noted in organoleptic evaluation are more closely associated with information gained from fresh fruit analyses than from the grade classifications of the dried fruit. There is definite need for development of more objective measures of quality of the dried fruit.

\section{SUMMARY}

The quality of dried French prunes in coastal regions is influenced primarily by size of crop and maturity of the fresh fruit, if proper dehydration practices are followed. Mature fruits from coastal areas may be selectively harvested because of natural abscission, in contrast to prunes from warmer interior valleys where abscission usually does not occur with a similar attainment of maturity. Thus, by multiple harvests the ripest prunes (that is, the softest and highest in soluble solids) are selectively harvested, making it possible to obtain good uniformity and high quality. However, a multiple harvest of four pickings did not result in better quality than three pickings, and both of these were only a little better than two, if the latter were properly timed to avoid heat damage to prunes dropped between harvests. Flesh firmness is the most satisfactory single index of maturity. Both flesh firmness and soluble solids content change perceptibly during maturation, but 
soluble solids content is influenced to a much greater degree by size of crop and cultural factors. Flesh color, although useful to indicate approaching maturity, does not change in sufficient degree or with such consistency during the final stage of maturation to be a precise harvest guide.

Flavor of prunes harvested from the tree and dried was preferred to that of ground-harvested dried fruit which had been heat injured while on the ground. When no heat injury occurred, flavor of fruit from the ground was preferred to that of fruit from the tree.

Fresh fruit stored in field containers for three days without refrigeration resulted in excessive losses due to fruit rots. Cold storage for as long as ten days was feasible for reducing fruit deterioration, but does not seem to be practical on a large scale.

\section{LITERATURE CITED}

Associntion of Official Agricultural Chemists

1945. Official and tentative methods of analysis. 6th Edition AOAC, Wash., D.C.

Clay POOL, L. L., and JoHN Kilbuck

1956. The influence of maturity of interior valley French prunes on the yield and quality of the dried product. Proc. Amer. Soc. Hort. Sci. 68:77-85.

Clay pool, L. L., W. H. Dempsey, Paul Esau, and M. W. Miller

Physical and chemical changes in French prunes during maturation in coastal valleys. Hilgardia $33(8): 311-18$.

Esat, Paul.

1958. Procedures for conversion of color data from one system to another. Food Tech. $12: 117$.

Maerz, A., and M. Rea PaUl

1930. A dictionary of color. McGraw-Hill Book Co., Inc., New York.

MaXie, E. C., and L. L. Claypoor

1957. Heat injury in prunes. Proc. Amer. Soc. Hort Sci. $69: 116-21$.

Nichols, P. F.

1935. Prune moisture content and processing. Fruit Products Journal, 14:211-13, 240$41,332-34,370-72$. 
The journal Hilgardia is published at irregular intervals, in volumes of about 600 pages. The number of issues per volume varies.

Subscriptions are not sold. The periodical is sent as published only to libraries, or to institutions in foreign countries having publications to offer in exchange.

You may obtain a single copy of any issue free, as long as the supply lasts; please request by volume and issue number from:

Agricultural Publications

Room 207 University Hall

2200 University Avenue

Berkeley 4, California

The limit to nonresidents of California is 10 separate issues on a single order. A list of the issues still available will be sent on request.

In order that the information in our publications may be more intelligible it is sometimes necessary to use trade names of products or equipment rather than complicated descriptive or chemical identifications. In so doing it is unavoidable in some cases that similar products which are on the market under other trade names may not be cited. No endorsement of named products is intended nor is criticism implied of similar products which are not mentioned. 